\title{
Article \\ COMMUNITY EMPOWERMENT MODEL FOR FOREST REVEGETATION AND PRESERVATION THE AREA AROUND THE SPRINGS: ARJUNA MOUNT CASE STUDY IN EAST JAVA, INDONESIA
}

\author{
Matheus Nugroho ${ }^{1}$, Soemarno ${ }^{2}$, Harsuko Riniwati ${ }^{3}$, Aminudin Afandhi ${ }^{4}$ \\ ${ }^{1}$ Student of Environmental Science Doctoral Program of Brawijaya University, Postgraduate Program in Malang, East \\ Java, Indonesia; mtnugroho@gmail.com \\ ${ }^{2}$ Faculty of Agriculture Brawijaya University in Malang, East Java, Indonesia; smno@ub.ac.id \\ ${ }^{3}$ Faculty of Fisheries and Marine Science Brawijaya University in Malang, East Java; Indonesia; \\ riniwatisepk@gmail.com \\ ${ }^{4}$ Faculty of Agriculture Brawijaya University in Malang, East Java, Indonesia; a.afandhi@gmail.com \\ Correspondence: mtnugroho@gmail.com ; Tel.: +62-81-3338-67954
}

\begin{abstract}
The research objectives were (1) to examine the determinants of community empowerment towards the revegetation of Arjuna mount forests; (2) assessing the influence of geography and soil conditions on the revegetation of Arjuna mount forests; (3) reviewing the effect of Arjuna mount forest revegetation on the preservation of spring water sources and (4) formulate a model of community empowerment around the forest based on revegetation of Arjuna mount and preservation of the area around the springs. The method used was descriptive method. While based on the techniques and tools used to research, the author uses the survey method to obtain facts that occur in the research area, namely in the area around the spring of the Kedunglarangan and Gumandar Prigen watersheds, Pasuruan Regency. Data obtained in the field are then processed and analyzed using GIS, ArcView 3.3 and Google Earth programs. The study population covering the community around the forest and springs, who lived in three villages, namely Leduk, Jatiarjo and Dayurejo village, Pasuruan, East Java-Indonesia. Data obtained from respondents with questionnaires and analyzed using SEM (structural equation modeling), to find out a general description of respondents' responses about community participation in the preservation of Arjuna mount forest. The results showed that (1) human resources, economic, social, local institutional factors, facilities and infrastructure had a very significant effect on forest revegetation; (2) geography and land variables have a significant effect on forest revegetation; (3) forest revegetation variables have a significant effect on the preservation of springs; and (4) The development of human resources, economic, local institutional, facilities and infrastructure in the community around the forest was a relevant model for the success of forest revegetation and the preservation of springs in Arjuna mount.
\end{abstract}

Keywords: community empowerment, springs, forest revegetation, Arjuna mount, soil and geographical conditions, plants vegetation profile

\section{Introduction}

The achievement of the forest sustainability function was characterized by the ability of the forest to support human life and the environment, in other words, a sustainable forest was a forest that was able to function all its functions. There were two functions of a healthy and sustainable forest, namely: (1) ecological function, meaning that the forest was able to guarantee the sustainability of a sustainable forest, a balanced interaction between all components in the forest; (2) economic function, meaning that forests that are damaged with a level of risk are still below the threshold of loss [42].

Rehabilitation of tropical forests by communities in a sustainable manner was important for forests as a function of the hydrological system, especially the effect of the sponge being able to hold rainwater and regulate its drainage, thereby reducing the occurrence of floods and maintaining the flow of water in the dry season. However, with the decrease in agricultural land, the increasing number of people living around the forest, the change in the management of protected forests into production forests and tourist destinations, the expansion of industrial investment areas, and 
the increasing needs of the community, these conditions result in uncontrolled harvesting. Forest resources include water, flora and fauna by human activities.

The monitoring results of United States Agency for International Development (USAID) showed that over the past 20 years there has been a rate of forest destruction on Arjuna mount, some areas of sub-watersheds have decreased springs discharge, this was allegedly related to forest damage in recharge areas continue to increase. The number of sources of dry or dead springs was 30 springs, out of a total of 41 springs. The main cause of the dry springs was damage to protected forests and production on Arjuna mount. Thousands of hectares of Arjuna mount forest are critical, due to fires and illegal logging. The forest area of Arjuna mount in the area of Pasuruan Regency reaches 12,000 hectares. About 1,500 hectares of them were damaged by fire in 2012 . Of the 1,500 hectares burned, only 300 hectares were rehabilitated. According to the study from the Clinton Foundation, USA in 2011-2012, the rate of forest destruction on Arjuna mount reached $0.24 \%$, equivalent to $68 \mathrm{ha} /$ year. If this condition continues, it will threaten clean water supplies for almost 2 million people in Pasuruan Regency, 4.7 thousand Ha of irrigated rice fields and around 500 industries in Pasuruan Regency [56].

Some of the efforts to conserve forests and springs include: the availability of funding sources for forest revegetation and rehabilitation, the existence of community institutions that serve as a platform for community aspirations and capacity for awareness and concern for forest conservation and springs, positive socio-cultural habits of the community in forest management and springs, such as community service and mutual cooperation, community knowledge of the importance of water for life [12]. This was clarified by [1], that the empowerment of forest communities regarding the rehabilitation, rehabilitation and conservation of forests has a significant influence on the contribution of damage to forest ecosystems.

The existence of forest communities was a component of the community that directly interacts with the surrounding forests, which provides an effective function for the success of forest conservation to save springs and biodiversity contained therein. The need for stages of empowering the surrounding community as a whole to achieve independence with the stages of awareness through counseling and training, capacity building and empowerment [22]. Development of communities around forests, with a condition based on human resource, socio-cultural, economic, community institutional structure, natural resources, environmental tourism, harmonization between institutions and community capabilities are appropriate strategies for the conservation of forest biodiversity [28]. Based on some of the facts and problems mentioned above, it was necessary to study the model of community empowerment of preservation of springs at Arjuna mount.

\section{Materials and Methods}

\subsection{Materials}

Data material was taken from the growth of plant species that exist in each area around the spring by recording and photographing parts that characterize the tree species. The next step was to measure water discharge in the dry and rainy seasons, water quality data. The results of plant species growth data will then be analyzed for plant density, relative density, frequency, relative frequency, importance value, and diversity index (Indriyanto, 2006).

This research was an associative problem, which was a research question that connects two or more variables. The relationship variable in research was a causal relationship, that was a causal relationship. There were independent or exogenous variables, and dependent or endogenous variables. Exogenous variables are selected according to consideration based on empirical conditions, forest revegetation activities and community empowerment around the year forest, the ability of researchers, the availability of supporting theories, and the characteristics of the study area [50].

Exogenous variables in this research plan were:

- Community empowerment (PM), including: human resources (PM1); economics (PM2); social (PM3); local institutions (PM4); facilities and infrastructure (PM5)

- Geography and land (GT), including: land slope (GT1); effective soil depth (GT2) There were 3 endogenous variables in this study, namely:

- RH, was a symbol of the Arjuna mount forest revegetation variable in the area of the Lajer, Dawuan, Sumberkuning and Watupereng springs, Prigen, Pasuruan, East Java, Indonesia, with indicators including: plant species (RH1); nurseries (RH2); fertilization (RH3); planting (RH4); care (RH5). Forest revegetation was determined by measuring the fulfillment of community empowerment; geography and land. 
- PVH, was a symbol of Arjuna mount vegetation and fauna profile variable, with indicators: vegetation stratification (PVH1); bird wealth (PVH2); taxonomy wealth (PVH3); plant density (PVH4). The profile of vegetation and fauna of Arjuna mount was determined by measuring the fulfillment of forest revegetation, geography and soil conditions and empowerment of communities around the forest.

- $\quad$ PSA, was a symbol for variable conservation of spring water, with indicators: water discharge in the rainy season (PSA1); water discharge in the dry season (PSA2); erosion (PSA3); economic value of water (PSA4). Conservation of springs is determined by measuring the fulfillment of forest vegetation and fauna profiles, revegetation of forests, geography and soil as well as the empowerment of communities around the forest.

\subsection{Methods}

The method used was descriptive method. While based on the techniques and tools used to research, the author uses the survey method to obtain facts that occur in the research area, namely in the area around the spring of the Kedunglarangan and Gumandar Prigen watersheds, Pasuruan Regency. Data obtained in the field are then processed and analyzed using GIS, ArcView 3.3 and Google Earth programs. The study population covering the community around the forest and springs, who lived in three villages, namely Leduk, Jatiarjo and Dayurejo Village, Pasuruan, East Java-Indonesia. Data obtained from respondents with questionnaires and analyzed using SEM (structural equation modeling), to find out a general description of respondents' responses about community participation in the preservation of Arjuna mount forest.

\section{Result}

\subsection{Community empowerment}

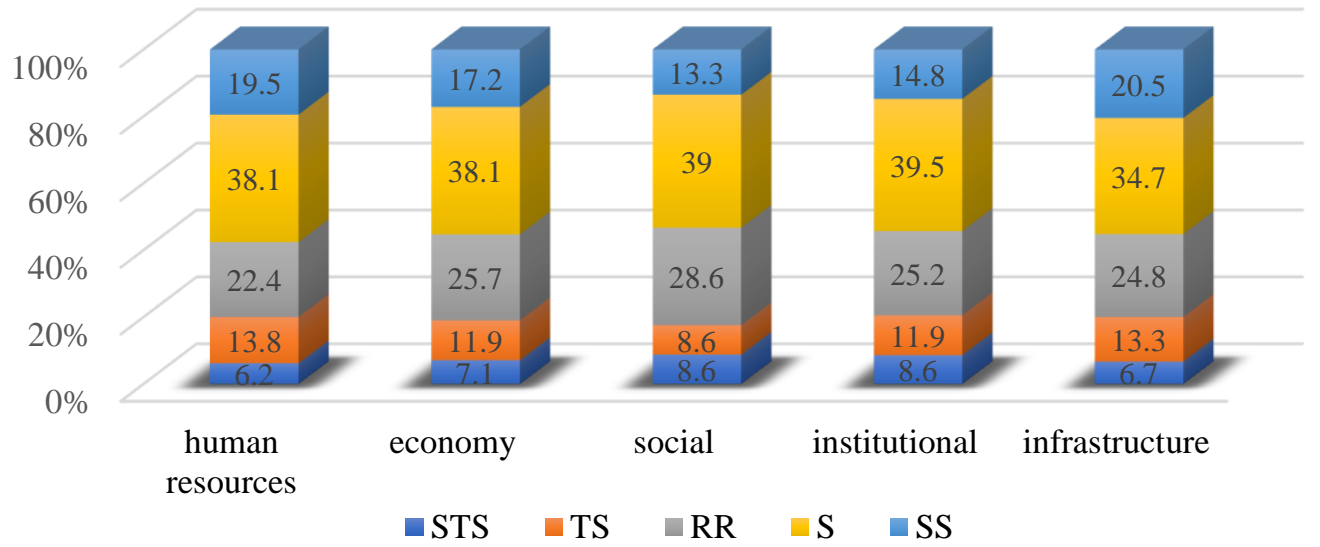

Figure 1. Respondents' perceptions of community empowerment

Note:

STS : explain the perceptions of respondents strongly disagree about community empowerment

TS : explain the perceptions of respondents disagree about community empowerment

RR : explain the perceptions of respondents hesitant about community empowerment

$\mathrm{S} \quad$ : explain the perceptions of respondents agreeing about community empowerment

SS : explain the perceptions of respondents strongly agree about community empowerment programs

\subsubsection{Human resources capital}

The profile of human resource empowerment in the communities of Leduk, Jatiarjo and Dayurejo Villages was:

(1) the minimum education level of junior secondary schools; (2) most of the main work of the farming community;

(3) there were jobs as breeders and fisheries; (4) there were people who have a side business, besides being farmers 
and breeders. The response of 210 respondents to the profile of human resources, in Figure 1. shows that human capital was a determinant of the success of community empowerment for the preservation of the Arjuna mount forest, because $57.6 \%$ of respondents said they strongly agreed and agreed. Figure 1. describes respondents' perceptions of empowerment in Leduk, Jatiarjo and Dayurejo villages.

\subsubsection{Economic capital}

The economic profile of empowering the people of Leduk, Jatiarjo and Dayurejo villages was: (1) the village community has a yard/field for agricultural business; (2) the average income of the community every month, at least 2 million and more; (3) the minimum number of dependents in one family was 3 people (wife, child, parent); (4) most citizens who have jobs and businesses have savings or assets; (5) most residents of Leduk or Jatiarjo and Dayurejo villages have family farms (such as chickens, goats or cows). The perception of 210 respondents to the economic profile of empowering the people of Leduk, Jatiarjo and Dayurejo villages, in Figure 1. shows that 55.3\% of respondents agreed and strongly agreed on community economic empowerment.

\subsubsection{Social capital}

The social profile of empowering the people of Leduk, Jatiarjo and Dayurejo villages was: (1) mutual cooperation activities were still being carried out in Leduk or Jatiarjo and Dayurejo villages; (2) most of the residents actively and voluntarily participate in mutual cooperation activities in the community; (3) the culture of social activities such as helping each other at death ceremonies, sick people, marriages and being hit by calamities still exist in the community; (4) most residents know that there was a revegetation program for the Arjuna mount forest; (5) community leaders (indigenous leaders, community leaders, hamlet and village heads, heads of neighborhood) participate actively in forest rehabilitation. The perception of 210 respondents to the social profile of empowering the people of Leduk, Jatiarjo and Dayurejo villages, in Figure 1. shows that the social capital of Leduk, Jatiarjo and Dayurejo villages was a determinant of the success of community empowerment for revegetation of the Arjuna mount forest, because almost $52.3 \%$ of respondents agreed and strongly agree.

\subsubsection{Local institutions}

The profile of local institutions for the empowerment of the people of Leduk, Jatiarjo and Dayurejo villages was: (1) the establishment of the forest village community institution in Leduk, Jatiarjo and Dayurejo villages; (2) the functions and responsibilities of the forest village community institution were responsible for revegetation and forest preservation; (3) communities around the forest actively engage in the implementation of forest revegetation programs (planning, financing, organization, implementation, monitoring and evaluation, and reporting); (4) forest village community institutions have cooperation with other parties in managing forests (companies, Indonesian state forest company, universities); (5) the forest village community institution in Leduk or Jatiarjo and Dayurejo villages in carrying out cooperation for revegetation of forests experience many obstacles that hinder the preservation of the Arjuna mount forest. The perception of 210 respondents to the profile of local institutions for the empowerment of the communities of Leduk, Jatiarjo and Dayurejo villages, in Figure 1. shows that the capital of local institutions, namely the forest village community institution Leduk, Jatiarjo and Dayurejo villages determines the success of community empowerment for revegetation of Arjuna mount forest, because it was almost $54.3 \%$ of respondents agreed and strongly agreed.

\subsubsection{Infrastructure}

The profile of facilities and infrastructure for empowering the people of Leduk, Jatiarjo and Dayurejo villages, namely: (1) access to the infrastructure of the entrance roads in Leduk, Jatiarjo and Dayurejo villages has been paved; (2) village transportation infrastructure such as motorcycle taxis were available; (3) clean water infrastructure was available for communities in Leduk, Jatiarjo and Dayurejo villages; (4) health infrastructure was available for communities in Leduk, Jatiarjo and Dayurejo villages; (5) basic education infrastructure such as buildings and supporting facilities for primary schools and buildings and supporting facilities for junior secondary schools was available for the community in Leduk, Jatiarjo and Dayurejo villages. The perception of 210 respondents to the profile of facilities and infrastructure for the empowerment of the people of Leduk, Jatiarjo and Dayurejo villages, in Figure 1. shows that the infrastructure of Leduk, Jatiarjo and Dayurejo villages was a determinant of the success of community 
empowerment for the preservation of Arjuna mount forest, because almost $55.2 \%$ of respondents agreed and strongly agreed.

\subsection{Soil and geographical conditions}

\subsubsection{Land slope}

The profile of the land slope for revegetation of Arjuna mount forest were: (1) the condition of the land planted at Lajer, Dawuan, Sumberkuning and Watupereng springs was sloping and hilly; (2) the condition of the slope of the tree planting land at the source of Lajer, Dawuan, Sumberkuning and Watupereng springs was steep; (3) in the rainy season the condition of land for planting trees in the springs of Lajer, Dawuan, Sumberkuning and Watupereng erosion; (4) on sloping slopping land in the area of the springs of Lajer, Dawuan, Sumberkuning and Watupereng the condition of the land material was rocky; (5) on sloping land along the springs area of Lajer, Dawuan, Sumberkuning and Watupereng sprouting landslides. The perception of 210 respondents towards the slope profile of the Lajer, Dawuan, Sumberkuning and Watupereng spring water source areas, in Figure 2. shows that $17.6 \%$ of respondents expressed strongly agree, $40 \%$ of respondents agreed, $25.7 \%$ of respondents expressed doubt, $13.8 \%$ of respondents expressed disagreement and $2.9 \%$ of respondents stated strongly disagree. Based on the respondents' perception data, Figure 2. states that the condition of the slope of the land around the spring has an effect on the success of revegetation of Arjuna mount forest, because almost $57.6 \%$ of respondents expressed strongly agree and agree with the profile of the slope of the land for revegetation of Arjuna mount forest.

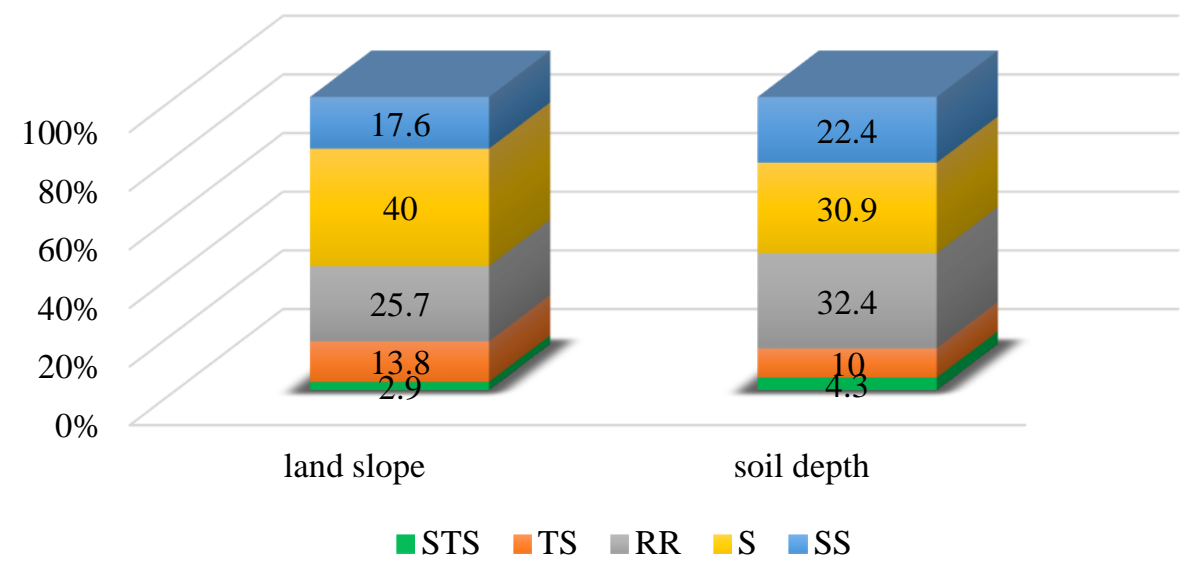

Figure 2. Respondents perceptions about geography and land

Note:

STS : explain the perceptions of respondents strongly disagree about community empowerment

TS : explain the perceptions of respondents disagree about community empowerment

RR : explain the perceptions of respondents hesitant about community empowerment

$\mathrm{S} \quad$ : explain the perceptions of respondents agreeing about community empowerment

SS : explain the perceptions of respondents strongly agree about community empowerment programs

\subsubsection{Soil depth}

The soil depth profile was effective for revegetation of Arjuna mount forest, namely: (1) the content of soil nutrients around the area of the Lajer, Dawuan, Sumberkuning and Watupereng springs were fertile; (2) trees can grow well (tall and enlarged) around the area of the spring of Lajer, Dawuan, Sumberkuning and Watupereng springs; (3) trees planted in roots penetrate strongly into the soil; (4) trees planted along the spring water source could absorb water in the rainy season and (5) tree species that grow around the area of the Lajer, Dawuan, Sumberkuning and Watupereng springs could prevent erosion in the rainy season. The perception of 210 respondents towards the effective soil depth 
profile of the Lajer, Dawuan, Sumberkuning and Watupereng springs area, in Figure 2. shows that $22.4 \%$ of respondents strongly agreed, $30.9 \%$ of respondents agreed, $32.4 \%$ of respondents expressed doubt - doubtful, $10 \%$ of respondents said they disagree, and $4.3 \%$ of respondents said strongly disagree. Based on these data states that the effective soil depth conditions around the springs affect the success of revegetation of the Arjuna mount forest, because almost $53.3 \%$ of respondents expressed strongly agree and agree. Figure 2. describes respondents' responses about the geographic and soil conditions of the Lajer, Dawuan, Sumberkuning and Watupereng spring water source areas.

\subsection{Forest revegetation}

\subsubsection{Plant species}

The profile of Arjuna mount forest plant species, namely: (1) the current vegetation condition of Arjuna mount forest plants, was better compared to 10 years ago; (2) the amount of vegetation of Arjuna's mount forest plants was currently increasing, and the source of the spring continues to flow; (3) the variety of plant species in the forests of Arjuna mount was currently increasing; (4) tree species planted in the forests of Arjuna mount were native plants of the forest; (5) what names of tree species planted in the forests of Arjuna mount include bamboo, kaliandra tree, rattan, banyan, sono tree, mahogany, rengas tree, kesambi tee, trengguli, tamarind trees. The perception of 210 respondents towards the profile of Arjuna mount forest plant species towards the preservation of the Lajer, Dawuan, Sumberkuning and Watupereng springs, in Figure 3. shows that $18.2 \%$ of respondents expressed strongly agree, $40.9 \%$ of respondents stated agree, $23.3 \%$ of respondents expressed doubt, $10.9 \%$ of respondents stated disagree and $6.7 \%$ of respondents stated strongly disagree. Based on these data the revegetation plant species of Arjuna mount forest influence the preservation of the Lajer, Dawuan, Sumberkuning and Watupereng springs, because almost $59.1 \%$ of respondents stated strongly agree and agree. Figure 3. explain the responses of respondents about the revegetation plant species of Arjuna mount forest.

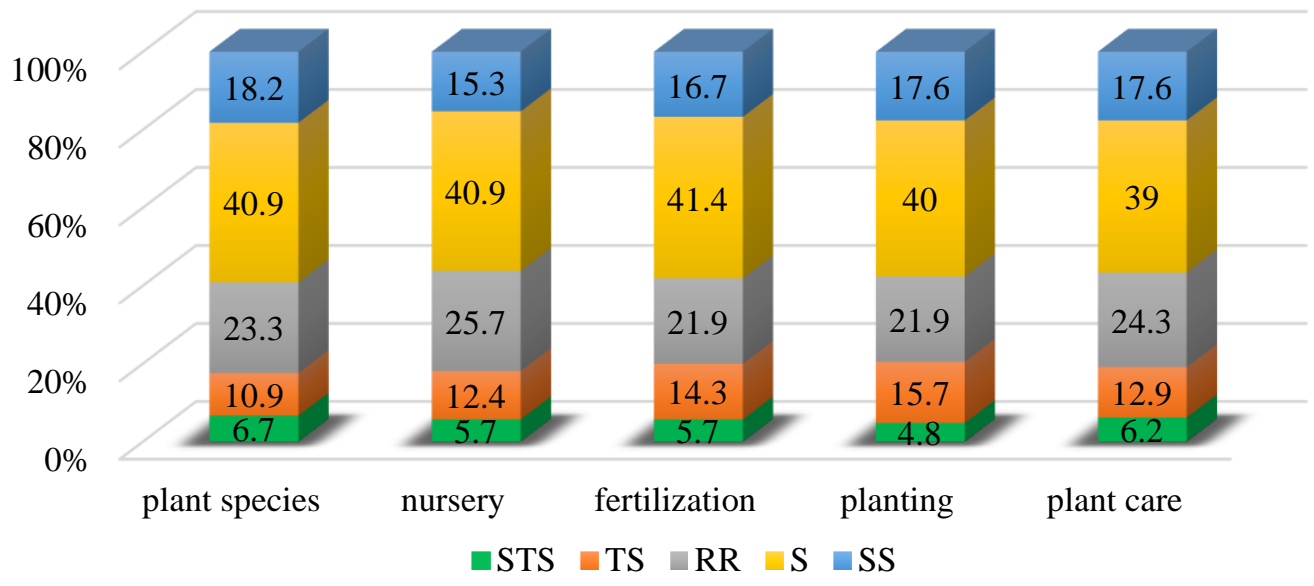

Figure 3. Respondent's perception of revegetation of Arjuna's mount forest

Note:

STS : explain the perceptions of respondents strongly disagree about community empowerment

TS : explain the perceptions of respondents disagree about community empowerment

RR : explain the perceptions of respondents hesitant about community empowerment

$\mathrm{S} \quad$ : explain the perceptions of respondents agreeing about community empowerment

SS : explain the perceptions of respondents strongly agree about community empowerment programs

\subsubsection{Nursery}

Profile of forest nursery plants in Arjuna mount, namely: (1) community members around the forest were involved and provide plant seeds for the preservation of Arjuna mount forest; (2) tree seedlings planted in the forests of Arjuna mount, originating from certified nurseries; (3) the height of the initial tree seedlings planted in the Arjuna mount 
forest was a minimum of 2 meters; (4) seed nursery function, before planting in Arjuna mount forest was quality and uniform seedlings and (5) the estimated price of seedlings for each tree with a height of 2 meters was around IDR 20,000 to IDR 25,000. The perception of 210 respondents to the profile of the Arjuna mount forest plant nursery towards the preservation of the Lajer, Dawuan, Sumberkuning and Watupereng springs, in Figure 3. shows that 15.3\% of respondents expressed strongly agree, $40.9 \%$ of respondents stated agree, $25.7 \%$ of respondents expressed doubt, $12.4 \%$ of respondents stated disagree and $5.7 \%$ of respondents stated strongly disagree. Based on these data, revealing that the nursery of Arjuna mount forest revegetation affects the preservation of the Lajer, Dawuan, Sumberkuning and Watupereng springs, because almost $56.2 \%$ of respondents stated strongly agree and agree. Figure 3 . explain the responses of respondents about the nursery of the Arjuna mount revegetation plant.

\subsubsection{Fertilization}

The profile of Arjuna mount forest plant fertilization includes: (1) plant fertilization was carried out by community farmers from the villages of Leduk, Jatiarjo and Dayurejo; (2) the purpose of fertilizing plants was to meet the adequacy of soil nutrients, and plant growth could be optimally optimized; (3) fertilizing the plants was done at the beginning of planting, and continuously every 3 months, until the age of the plants was 3 years; (4) the type of fertilizer given to fertilizing plants was inorganic fertilizer (NPK) and organic (manure); (5) NPK fertilization method for each plant was fertilizing by circling around the plant. The perception of 210 respondents towards the profile of Arjuna mount forest plant fertilization towards the preservation of the Lajer, Dawuan, Sumberkuning and Watupereng springs, in Figure 3. shows that $16.7 \%$ of respondents expressed strongly agree, $41.4 \%$ of respondents stated agree, $21.9 \%$ of respondents expressed doubt, $15.7 \%$ of respondents stated disagree and $4.8 \%$ of respondents stated strongly disagree. Based on these data, revealing the fertilization of Arjuna mount forest vegetation affects the preservation of the Lajer, Dawuan, Sumberkuning and Watupereng springs, because almost $58.1 \%$ of respondents agreed and strongly agreed. Figure 3. explain the responses of respondents about the fertilization of Arjuna mount forest revegetation plants.

\subsubsection{Planting}

Profile of Arjuna mount forest tree planting includes: (1) managing the forest together with the government, applying strict regulations to the lawbreakers of forest destruction and actively involved in tree planting activities and caring for them were a number of forest management activities, so that they could continue to benefit humans and their environment; (2) The Village Government makes village regulations for forest management; (3) tree planting, width and distance between trees, greatly affect plant growth; (4) spacing and number of trees planted in forest revegetation was 3 meters x 3 meters (300 trees/ha); (5) a simple procedure for planting trees was to make holes and plant tree seeds in an upright position, as deep as $3 \mathrm{~cm}$ from the neck of the root, and cover the soil again. The perception of 210 respondents to the profile of Arjuna mount forest planting on the preservation of the Lajer, Dawuan, Sumberkuning and Watupereng springs, in Figure 3. shows that $17.6 \%$ of respondents expressed strongly agree, $40 \%$ of respondents stated agree, $21.9 \%$ of respondents expressed doubt, $15.7 \%$ of respondents stated disagree and $4.8 \%$ of respondents stated strongly disagree. Based on these data stated the planting of Arjuna mount forest trees influence the preservation of the Lajer, Dawuan, Sumberkuning and Watupereng springs, because almost 57.6\% of respondents agreed and strongly agreed. Figure 3. explain the responses of respondents about the planting of Arjuna mount forest trees.

\subsubsection{Plant care}

The profile of Arjuna's mount forest care includes: (1) care was needed to maintain the plants so they were not damaged after planting; (2) maintenance activities include: cleaning plants from grass, weeding plants, making firebreaks during the dry season, reporting treatment results to forest village community institutions once every 1 month, and then evaluating them; (3) the duration of plant maintenance was carried out once a week, for 3 years after planting; (4) the plant maintenance process was also carried out monitoring activities, which include direct growth checking, which was done every 3 months; (5) caring for plants includes prevention of plant diseases, fertilizing and administering drugs, weeding from weeds, providing water during the dry season and protecting plants from natural and human damage. The perception of 210 respondents towards the care profile of Arjuna mount forest plants towards the preservation of the spring water source of Lajer, Dawuan, Sumberkuning and Watupereng, in Figure 3. shows that $17.6 \%$ of respondents stated strongly agree, $39 \%$ of respondents agreed, $24.3 \%$ respondents expressed doubt, $12.9 \%$ of respondents expressed disagreement and $6.2 \%$ of respondents stated strongly disagree. Based on these data, revealing the maintenance of Arjuna mount forest vegetation affects the preservation of the Lajer, Dawuan, 
Sumberkuning and Watupereng springs, because almost $56.5 \%$ of respondents said they agree and strongly agree. Figure 3. explains the respondent's response to the maintenance of Arjuna mount forest revegetation plants.

\subsection{Plant vegetation profile}

\subsubsection{Vegetation stratification}

The profile of the vegetation stratification in the Arjuna mount forest includes: (1) the height of trees planted around the spring after 3 years reaching a range of 20-25 meters; (2) canopy of canopy trees interlocked, so that forest trees become green and shady; (3) the height of trees planted around the spring area of Lajer, Dawuan, Watupereng and Sumberkuning was also in the range of 4-20 meters; (4) there were many shrubs and shrubs in the lower part of the tree which were in the range of 1-4 meters; (5) most of the soil around the source area of the spring is covered with cover crops such as grass and other thickets. The perception of 210 respondents to the Arjuna mount forest stratification profile towards the springs preservation of Lajer, Dawuan, Sumberkuning and Watupereng, in Figure 4. explains that $20.9 \%$ of respondents stated strongly agree, $37.2 \%$ of respondents agreed, $23.4 \%$ of respondents expressed doubt, $15.2 \%$ of respondents said they did not agree and $3.3 \%$ of respondents stated strongly disagree. Based on these data, the vegetation profile of the Arjuna mount forest stratification influences the springs preservation of in Lajer, Dawuan, Sumberkuning and Watupereng, because almost $58.1 \%$ of respondents agreed and strongly agreed. Figure 4. explains the responses of respondents about the vegetation stratification profile of the Arjuna mount forest.

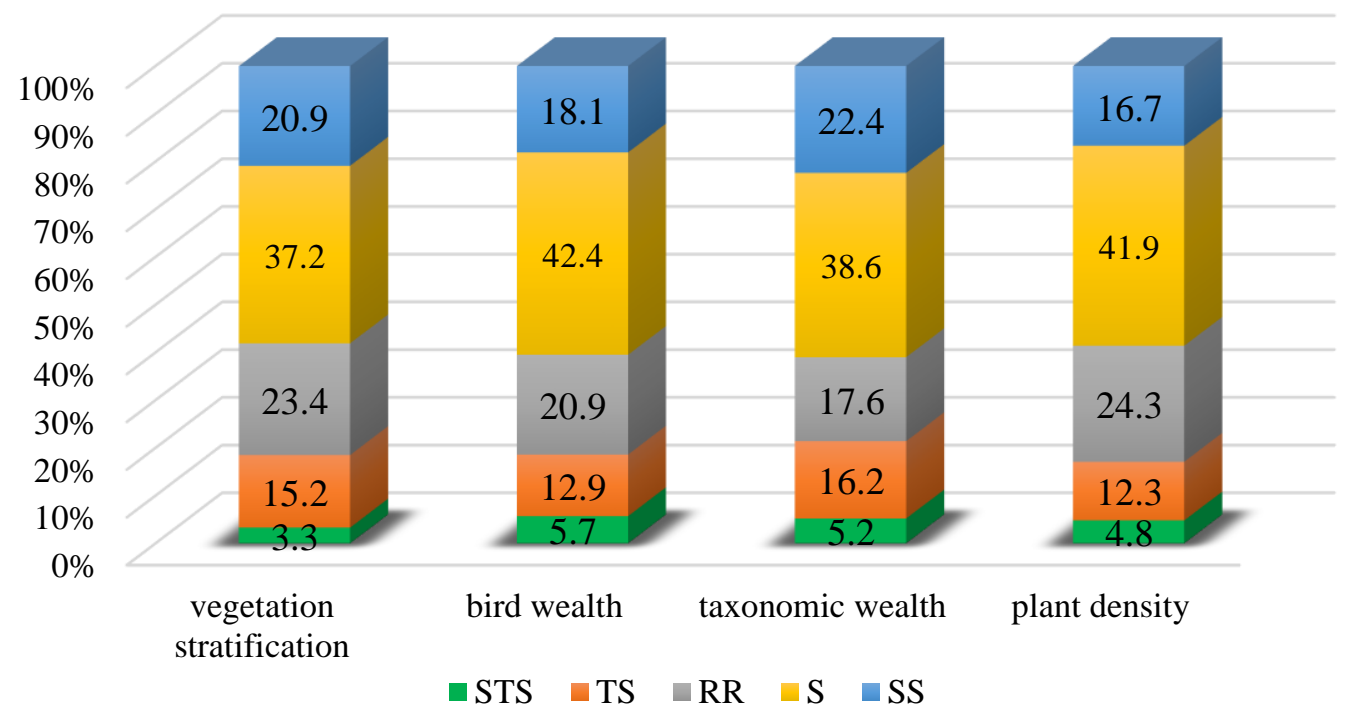

Figure 4. Respondents' perceptions of plant vegetation profile

Note:

STS : explain the perceptions of respondents strongly disagree about community empowerment

TS : explain the perceptions of respondents disagree about community empowerment

RR : explain the perceptions of respondents hesitant about community empowerment

$\mathrm{S} \quad$ : explain the perceptions of respondents agreeing about community empowerment

SS : explain the perceptions of respondents strongly agree about community empowerment programs

\subsubsection{Bird wealth}

The profile of the Arjuna mount forest birds wealth includes: (1) there were regulations for the protection of animal species in the forest area of Arjuna mount; (2) several species of birds, such as finches, greens cucak, parrots, trocok, crabs can still be found in the forest area of Arjuna mount; (3) various birds such as finches, green cucak, parrots, trocok, kepodang could develop on their own in the forest area of Arjuna mount; (4) based on the species protection 
law that various species of birds such as finches, green cucak, parrots, trocok, ferns are protected from poaching activities; (5) there was the application of social sanctions for community members who hunt birds in the forest. Perception of 210 respondents to the bird wealth profile in the Arjuna mountain forest area, in Figure 4. shows that $18.1 \%$ of respondents stated strongly agree, $42.4 \%$ of respondents agreed, $20.9 \%$ of respondents expressed doubt, $12.9 \%$ of respondents expressed disagreement and $5.7 \%$ of respondents stated strongly disagree. Based on these data, the bird wealth profile of the Arjuna mount forest area illustrates the preservation of the springs of the springs of Lajer, Dawuan, Sumberkuning and Watupereng, because almost $60.5 \%$ of the respondents agreed and strongly agreed. Figure 4. explains the respondent's response to the profile of Arjuna mount forest bird wealth.

\subsubsection{Taxonomic wealth}

The taxonomic wealth profile of the Arjuna mount forest includes: (1) tree planting in the spring area; (2) planting various types of trees, endemic plants, springs and fruit plants; (3) plant maintenance by forest farmers; (4) increasing forest biodiversity; (5) caring for forest biodiversity. Perception of 210 respondents to the forest taxonomy profile of Arjuna mount, in Figure 4. shows that $22.4 \%$ of respondents agreed strongly agree, $38.6 \%$ of respondents agreed, $17.6 \%$ of respondents expressed doubt, $16.2 \%$ of respondents expressed disagreement and $5.2 \%$ of respondents stated strongly disagree. Based on these data stated the taxonomic wealth profile of the Arjuna mount forest illustrates the springs vegetation preservation in Lajer, Dawuan, Sumberkuning and Watupereng, this was evidenced by the perception of respondents of $61 \%$ agreeing and strongly agree. Figure 4. explains the respondent's response to the taxonomic profile of the Arjuna mount forest.

\subsubsection{Plant density}

The density profile of the Arjuna mount forest plant includes: (1) the distance of the dense and lush plants; (2) the density of plants increases, between trees more and more branches and leaves; (3) plant density was maintained and not damaged; (4) the number of tree stands was very large; (4) plant density can prevent erosion or landslides in the rainy season. The perception of 210 respondents towards the Arjuna mount forest plant density profile, in Figure 4. shows that $16.7 \%$ of respondents strongly agreed, $41.9 \%$ of respondents agreed, $24.3 \%$ of respondents expressed doubt, $12.3 \%$ of respondents stated disagree and $4.8 \%$ of respondents stated strongly disagree. Based on these data the density profile of the Arjuna mount forest plant illustrates the preservation of the vegetation of the spring springs of Lajer, Dawuan, Sumberkuning and Watupereng, because almost $58.6 \%$ of respondents said they agreed and strongly agreed. Figure 4. explains the respondent's response to the Arjuna mount forest density profile.

\subsection{Springs preservation}

\subsubsection{Rainy season water discharge}

Profile of water discharge in the rainy season from springs in the forests of Arjuna mount, among others: (1) water debit increases; (2) water sources were used for drinking water and residents' water needs; (3) residents' trash was found along the river flow; (4) large water discharge and turbid water color; (5) large water discharge and clear water color. The perception of 210 respondents towards the profile of the Arjuna mount spring water source in the rainy season, in Figure 5. shows that $24.8 \%$ of respondents expressed strongly agree, $35.7 \%$ of respondents stated agree, $19.5 \%$ of respondents expressed doubt, $16.2 \%$ of respondents stated disagree and $3.8 \%$ of respondents stated strongly disagree. Based on these data, the profile of the Arjuna mount spring discharge in the rainy season illustrates the preservation of the vegetation of the Lajer, Dawuan, Sumberkuning and Watupereng springs, because almost $60.5 \%$ of respondents agreed and strongly agreed. Figure 5. explain the responses of respondents about the profile of the Arjuna mount spring discharge in the rainy season

\subsubsection{Dry season water discharge}

Profile of water discharge in the dry season from springs in Arjuna mount forest, among others: (1) the condition of springs in the dry season the water continues to flow and the color of the water was clear; (2) in the dry season the spring water source dies, dry time occurs 4 months or more; (3) in the dry season the spring water source dies, the dry season occurs less than 3 months; (4) revegetation activities of Arjuna mount forest in the area around the spring; (5) density of plants in the area around the spring was denser than in the previous year. The perception of 210 respondents toward the Arjuna mount spring water discharge profile in the dry season, in Figure 5. shows that 19.5\% of respondents 
expressed strongly agree, $37.2 \%$ of respondents stated agree, $23.3 \%$ of respondents expressed doubt, $14.8 \%$ of respondents stated disagree and $5.2 \%$ of respondents stated strongly disagree. Based on these data, the profile of the Arjuna mount spring water discharge profile in the dry season illustrates the vegetation of the spring springs of Lajer, Dawuan, Sumberkuning and Watupereng, because almost $56.7 \%$ of respondents agreed and strongly agreed. Figure 5. explain the responses of respondents about the profile of the Arjuna mount spring water source in the dry season.

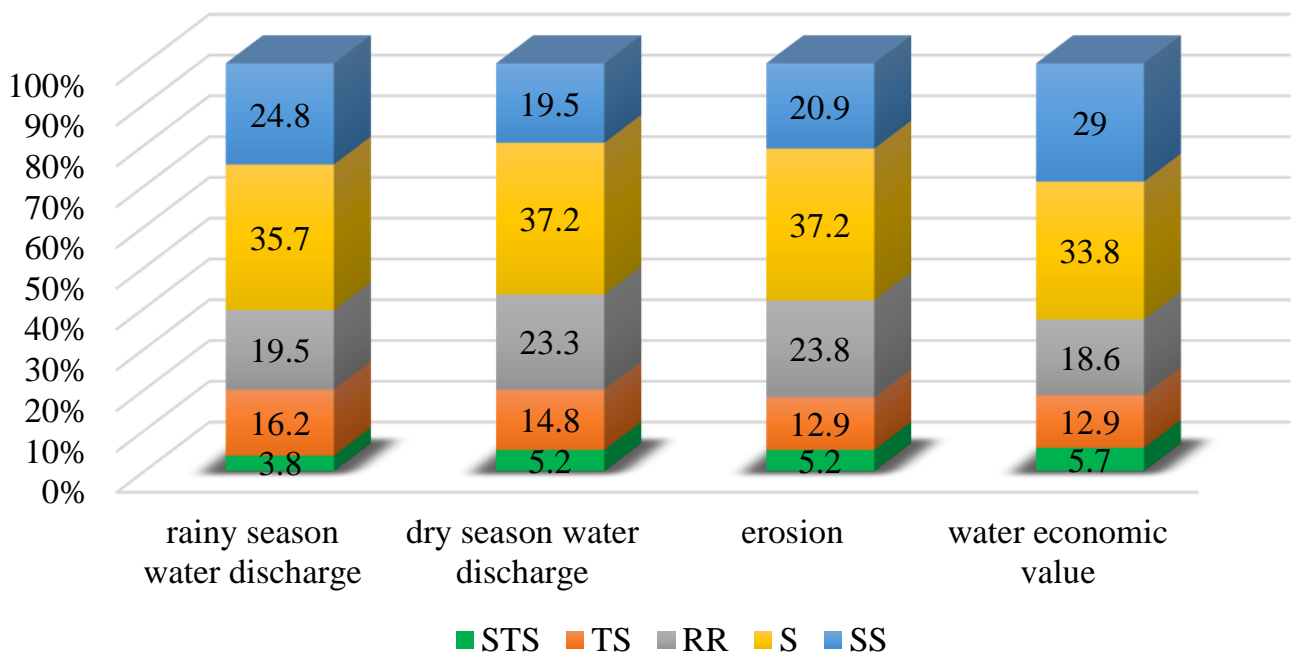

Figure 5. respondents regarding the springs preservation

Note:

STS : explain the perceptions of respondents strongly disagree about community empowerment

TS : explain the perceptions of respondents disagree about community empowerment

RR : explain the perceptions of respondents hesitant about community empowerment

$\mathrm{S}$ : explain the perceptions of respondents agreeing about community empowerment

SS : explain the perceptions of respondents strongly agree about community empowerment programs

\subsubsection{Erosion}

The profile of land erosion conditions around the spring springs in Arjuna mount forest, among others: (1) during the rainy season springs occur; (2) turbid-colored water flow; (3) landslides and erosion occur around the spring area; (4) trees planted around the spring source area can prevent erosion and flooding; (5) the flow of water in the rainy season from the spring remains clear. The perception of 210 respondents on the condition of land erosion around the spring source area, in Figure 5. explained that 20.9\% of respondents expressed strongly agree, $37.2 \%$ of respondents stated agree, $23.8 \%$ of respondents expressed doubt, $12.9 \%$ of respondents stated disagree and $5.2 \%$ of respondents stated strongly disagree. Based on these data, the erosion conditions of vegetation land in the Lajer, Dawuan, Sumberkuning and Watupereng springs area affect the sustainability of the spring water source area, because almost $58.1 \%$ of respondents said they agree and strongly agree. Figure 5. explain the responses of respondents about the condition of erosion of land around the spring of Arjuna mount.

\subsubsection{Water economic value}

The economic value of Arjuna mount forest springs includes: (1) the discharge and quality of water produced by the spring in the rainy season was large and the color was murky; (2) the discharge and quality of water produced from dry season springs was small and the color was clear; (3) debit of large spring sources and clear colors, the economic price of water increases, because the quality and healthy mountain water for the needs of the community and industry; (4) Arjuna mountain water was widely used, and sold as industrial mineral bottled water; (5) Arjuna mountain forest as a superior water source that has quality and economic value for the community. The perception of 210 respondents towards the economic value of Arjuna mount forest water, in Figure 5. explained that $29 \%$ of respondents expressed 
strongly agree, $33.8 \%$ of respondents stated agree, $18.6 \%$ of respondents expressed doubt, $12.9 \%$ of respondents stated disagree and $5.7 \%$ of respondents stated strongly disagree. Based on these data explain the economic value of the spring water sources of Lajer, Dawuan, Sumberkuning and Watupereng were significant for the needs of society and industry, because nearly $62.8 \%$ of respondents agreed and strongly agreed. Figure 5. explain the responses of respondents about the economic value of Arjuna mount forest water.

\subsection{SEM (structural equation modeling)}

Some requirements that must be met in the SEM analysis include requirements for sample size, normality requirements and requirements for the absence of multicollinearity in the model.

- Adequacy of sample amounts

The minimum sample size for SEM analysis with the Maximum Likelihood estimation method was 100 to 200 [24]. The number of samples used in this study was 210 samples, which means the number of samples has exceeded the adequacy requirement of the sample size in SEM analysis.

- Normality test

Normality test in SEM analysis was intended to determine the normal or not distribution of the research of each variable. Normality evaluation was done by using critical ration skewness value, the data was said to be normally distributed if the critical ratio skewness value was below the absolute price 2.58 [24], while in [20], the multivariate CR value below 8 was still acceptable and analysis can still be continued as long as all indicators have CR curtosis < in susceptible value $-2.58<\mathrm{z}<2.58$. The following are the results of the data normality test in the model Table 1 .

The results of the normality test indicate that the research data has been normally distributed because the univariate CR skewness value of all variables has been in the interval $-2.58<\mathrm{z}<2.58$ so that it can be concluded that the data analyzed has fulfilled the univariate normality, then, the multivariate CR value has also been was in the range of -2.58 $<\mathrm{z}<2.58$ so that multivariate can be declared normal, thus it can be concluded that the research data also meets the assumptions of multivariate normality.

Table 1. Assessment of normality

\begin{tabular}{lrrrrrr}
\hline Variable & $\min$ & $\max$ & skew & c.r. & kurtosis & c.r. \\
\hline Plant density & 1.000 & 5.000 & -0.585 & -3.459 & -0.223 & -0.658 \\
Taxonomic wealth & 1.000 & 5.000 & -0.553 & -3.273 & -0.616 & -1.822 \\
Bird wealth & 1.000 & 5.000 & -0.635 & -3.755 & -0.289 & -0.854 \\
Vegetation stratification & 1.000 & 5.000 & -0.444 & -2.629 & -0.586 & -1.735 \\
Economic value of water & 1.000 & 5.000 & -0.648 & -3.832 & -0.510 & -1.507 \\
Erosion & 1.000 & 5.000 & -0.538 & -3.185 & -0.425 & -1.258 \\
Water discharge in the dry season & 1.000 & 5.000 & -0.484 & -2.863 & -0.539 & -1.594 \\
Water discharge in the rainy season & 1.000 & 5.000 & -0.500 & -2.957 & -0.680 & -2.013 \\
Plant species & 1.000 & 5.000 & -0.648 & -3.833 & -0.218 & -0.645 \\
Nursery & 1.000 & 5.000 & -0.568 & -3.360 & -0.251 & -0.743 \\
Fertilization & 1.000 & 5.000 & -0.565 & -3.342 & -0.406 & -1.201 \\
Planting & 1.000 & 5.000 & -0.498 & -2.949 & -0.519 & -1.536 \\
Care & 1.000 & 5.000 & -0.551 & -3.262 & -0.379 & -1.120 \\
Land slope & 1.000 & 5.000 & -0.461 & -2.728 & -0.399 & -1.181 \\
Effective soil depth & 1.000 & 5.000 & -0.439 & -2.596 & -0.206 & -0.608 \\
Human Resources & 1.000 & 5.000 & -0.542 & -3.204 & -0.485 & -1.434 \\
Economy & 1.000 & 5.000 & -0.553 & -3.270 & -0.365 & -1.079 \\
Social & 1.000 & 5.000 & -0.582 & -3.442 & -0.264 & -0.780 \\
Local institutions & 1.000 & 5.000 & -0.573 & -3.392 & -0.391 & -1.155 \\
Facilities and infrastructure & 1.000 & 5.000 & -0.491 & -2.906 & -0.541 & -1.601 \\
\hline Multivariate & & & & & -10.096 & -2.466 \\
\hline
\end{tabular}


The results of the normality test indicate that the research data has been normally distributed because the univariate CR skewness value of all variables has been in the interval $-2.58<\mathrm{z}<2.58$ so that it can be concluded that the data analyzed has fulfilled the univariate normality, then, the multivariate CR value has also been was in the range of -2.58 $<\mathrm{z}<2.58$ so that multivariate can be declared normal, thus it can be concluded that the research data also meets the assumptions of multivariate normality.

Table 2. Test results of signifikansi regression weights

\begin{tabular}{|c|c|c|c|c|c|c|c|}
\hline & & & Estimate & S.E. & C.R. & $\mathrm{P}$ & Label \\
\hline Forest revegetation & $<--$ & $\begin{array}{l}\text { Community } \\
\text { empowerment }\end{array}$ & 0.374 & 0.075 & 5.005 & $* * *$ & par_15 \\
\hline Forest revegetation & $<--$ & $\begin{array}{l}\text { Geography and } \\
\text { land }\end{array}$ & 0.679 & 0.108 & 6.273 & $* * *$ & par_16 \\
\hline Forest vegetation profile & $<--$ & $\begin{array}{l}\text { Forest } \\
\text { revegetation }\end{array}$ & 0.312 & 0.101 & 3.084 & 0.002 & par_18 \\
\hline Forest vegetation profile & $<--$ & $\begin{array}{l}\text { Geography and } \\
\text { land }\end{array}$ & 0.750 & 0.141 & 5.299 & $* * *$ & par_20 \\
\hline $\begin{array}{l}\text { Preservation of spring } \\
\text { water }\end{array}$ & $<---$ & $\begin{array}{l}\text { Forest } \\
\text { revegetation }\end{array}$ & 0.503 & 0.087 & 5.760 & $* * *$ & par_17 \\
\hline $\begin{array}{l}\text { Preservation of spring } \\
\text { water }\end{array}$ & $<--$ & $\begin{array}{l}\text { Community } \\
\text { empowerment }\end{array}$ & 0.256 & 0.059 & 4.344 & $* * *$ & par_19 \\
\hline $\begin{array}{l}\text { Preservation of spring } \\
\text { water }\end{array}$ & $<--$ & $\begin{array}{l}\text { Forest } \\
\text { vegetation } \\
\text { profile }\end{array}$ & 0.241 & 0.083 & 2.914 & 0.004 & par_21 \\
\hline
\end{tabular}

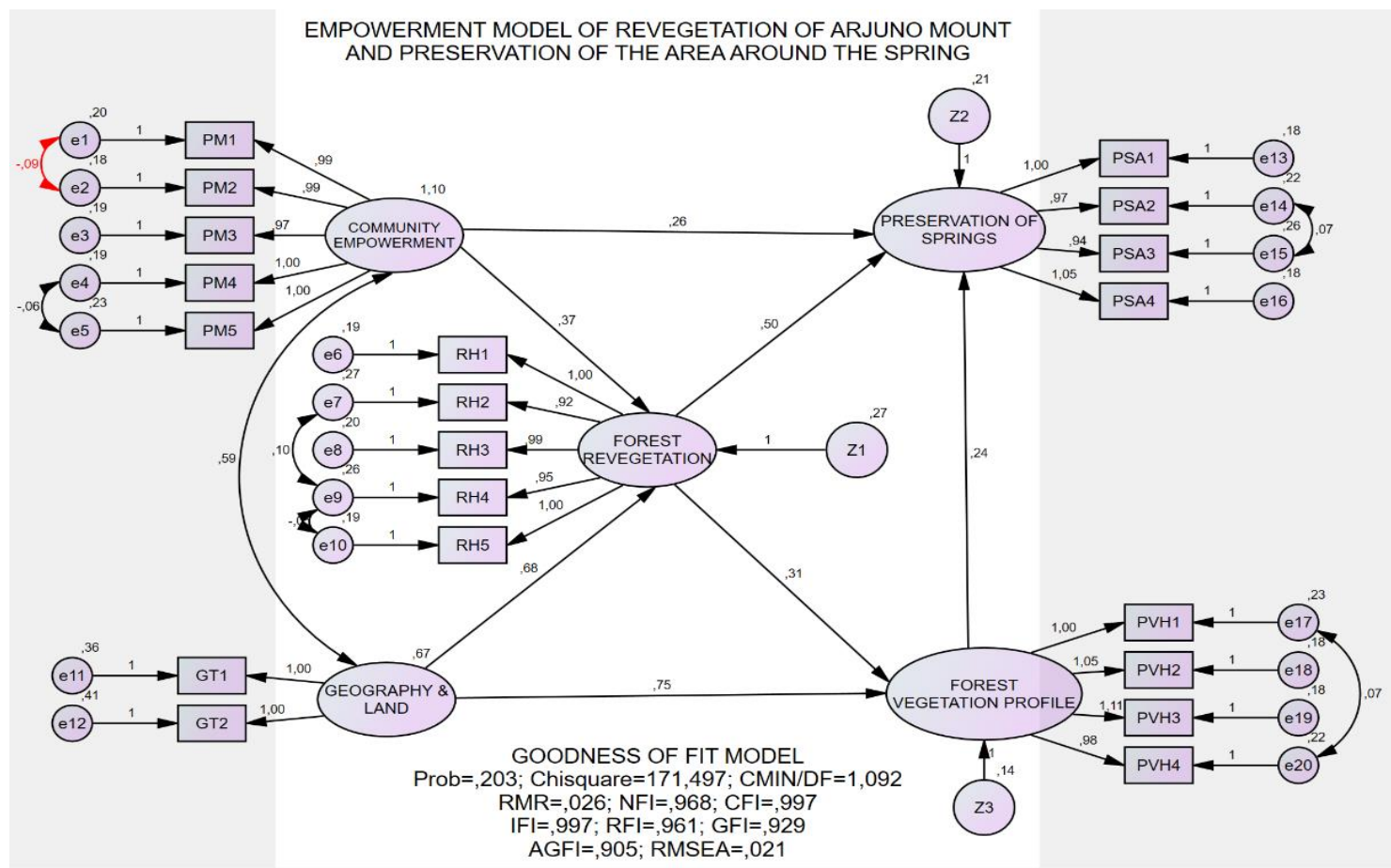

Figure 6. Results of estimation of structural model modifications 


\section{- Outlier}

Outliers are observations that arise with extreme values both univariate and multivariate which arise because the combination of unique characteristics that they have and looks very different from other observations. In SEM analysis, outliers can see the mehalonobis distance value, the data was referred to as an outlier if the Mahalanobis d-squared value exceeds 45,314 that was the Chi Square value at 20 degrees free (because there are 20 valid indicators analyzed) and a significant level of 0,001 . Outlier detection results show that out of 210 data analyzed there was no data that has an mahalonobis distance at 45.314 which means 210 analyzed data does not contain outliers.

- Uji multikolinearitas

Multicollinearity test was done by looking at the correlation values between endogenous variables. The model was declared free of multicollinearity if the correlation value between endogenous variables was $<0.9$. The multicolienarity test results show an estimate value of 0.696 , meaning that there were no endogenous variables that have a correlation $>$ 0.9 , this means there was no multicollinearity in SEM model.

\subsubsection{Structural model testing}

Structural model testing was used to test the research hypothesis. Stages in structural model testing include structural model formation stage, structural model feasibility test and test the significance of the influence of endogenous variables on endogenous variables.

- Structural model specifications

By referring to the hypotheses and framework of the model constructed in this study, the specification of the structural model of SEM analysis built in this study was as follows:

- Structural model suitability test

The suitability test of the structural model in SEM analysis was done by looking at some criteria of Goodness of fit model such as Chi Square value, probability, df, GFI, AGFI, TLI, CFI RMSEA and RMR. In this test, the structural model was stated to have fulfilled the Goodness of fit model criteria if the model meets one of the assumptions contained in the table above. [19] states that if there are one or two goodness-of-fit criteria that have been fulfilled, then it can be said that the model built was good. Based on the estimation results of the structural measurement shows that the structural model has not been so good in meeting the criteria of goodness of fit model, the probability of the model was still below 0.05 , which means that with the model, 210 samples have not had the same covariance matrix with the actual population covariance matrix, so it was necessary to modify the model. Modification indices to increase the goodness of fit model, then add paths between error e1 and e2, e4 and e5, e7 and e9, e9 and e10, e17 and e20, and in the path between e14 and e15. The results of the goodness of fit model test after the three lines were added presented in Figure 6. shows that after the modification of the model, the model has a probability above 0.05 , thus, the model has been used to test the hypothesis in this study.

- Significance test

The significance test aims to examine whether there was a significant influence of exogenous variables on endogenous variables. The hypothesis built in this test was as:

H0: There was no significant effect of exogenous variables on endogenous variables

H1: There was a significant effect of exogenous variables on endogenous variables, with a significant level of 0.05 , $\mathrm{H} 0$ will be rejected if significant values $(\mathrm{P})<0.05$ and $\mathrm{CR}>1.96$, while if the significant value $(\mathrm{P})>0.05$ and $\mathrm{CR}<$ 1.96 then $\mathrm{H} 0$ was not rejected.

\subsubsection{Simultaneous influence}

The contribution of exogenous to endogenous variables was shown by the squared multiple correlation value of each endogenous variable. Based on the results of the analysis in the contribution of exogenous variables to endogenous variables were as follows:

- Squared multiple correlation value of forest revegetation variable was 0.737 , this indicates that the contribution given by the community empowerment and geography \& land variables to forest revegetation was $73.7 \%$, while the remaining $26.3 \%$ variance forest revegetation was influenced by other factors beyond community empowerment and geography and land.

- Squared multiple correlation value of forest vegetation profile variable was 0.850 , this indicates that the contribution given by forest revegetation, community and geography \& land variables to forest vegetation profile 
was $85.0 \%$, while the rest was as much as $15.0 \%$ of the variance in forest vegetation profiles was influenced by factors other than forest revegetation, community empowerment and geography and land.

- Squared multiple correlation value of the springs source preservation variable was 0.809 , this indicates that the contribution given by the community and geography \& land empowerment variables to the preservation of springs was $80.9 \%$, while the remaining 19 were, $1 \%$ of the variance in the preservation of springs was influenced by other factors beyond community empowerment and geography and land.

\section{Discussion}

\subsection{Community empowerment}

\subsubsection{Human resources capital}

The constraints of human resources related to the empowerment of communities in Leduk, Jatiarjo and Dayurejo Villages were the level of education of the community as farmers in general was junior high school and elementary school. The survey results showed that there were 7 formal education institutions, 10 elementary schools, 4 junior high schools, non formal, 2 pursuit packages $\mathrm{C}$ and 3 Islamic boarding schools. There are 361 active members in women's organizations, 178 youth organizations, and professional organizations such as 69 people. Based on these data, the community was conditioned to develop dryland agriculture as the basis of their livelihood, and some do livestock business. The lack of knowledge and skills of the community around the forest, so that people use the forest as their main source of income, this has resulted in them doing things that are actually a factor in forest destruction. The level of community education has a significant effect on community empowerment and forest revegetation. [1], explained that the education of rural communities regarding forest conservation has a significant influence on preventing damage to forest ecosystems.

The successes that have been carried out in the development of human resources in Leduk, Jatiarjo and Dayurejo villages include: (1) the formation of a group discussion of communities around the source of water; (2) an environmental school was held once a week, every Sunday by the Cempaka Foundation; (3) livestock skills training activities and (4) tourism service business development, the Arjuna mount forest area has high tourism potential.

Based on the results of surveys and socialization in group discussions, the 2 objectives to be implemented in human resource empowerment in Leduk, Jatiarjo and Dayurejo villages were: (1) increasing knowledge and changing attitudes of the community, towards the revegetation movement of the Arjuna mount forest and (2) the environmental school model, which implements education on forest conservation and biodiversity through a local competency-based curriculum by the Cempaka foundation. According to [17], knowledge can be influenced by formal education factors. Knowledge was very closely related to education, where it was expected that with higher education, then the person will be more knowledgeable.

\subsubsection{Economic capital}

The constraints on economic conditions related to the empowerment of communities in Leduk, Jatiarjo and Dayurejo villages were the increasing economic pressure and family needs, which has an impact on changing the function of forests into agricultural fields. Looking at the natural conditions, the people of Leduk, Jatiarjo and Dayurejo Villages were conditioned to develop dryland agriculture as the basis for their livelihoods. In its development, most of the community's agricultural land that has been sold to people outside the area has made them penetrate the forest as agricultural land. The economic limitations of the surrounding forest communities and the absence of awareness of the dangers caused by land clearing make them plant annual crops in an effort to meet their daily needs. Weak law enforcement on regulations on forest use makes communities together and in large numbers clear land in the forest [56].

The successes that have been carried out in economic empowerment in Leduk, Jatiarjo and Dayurejo villages include: (1) increasing the economic value of families through organic farming, goat farming, wasp honey and tourism services around the Arjuna mountain forest. overcome because economic needs can be fulfilled; (2) forest village community institutions carry out forest conservation effectively based on ecological, economic and social aspects; (3) community economic empowerment projects such as presidential instructions of backward village, infrastructure programs that support underdeveloped villages, regional advancement program, people's business credit, community development and empowerment and poverty alleviation programs in urban areas. These programs generally have 
similar dimensions of approach, such as: revolving capital assistance, infrastructure development assistance, local institutional development, strengthening and development of business partnerships, and facilitation of mentoring [26].

Based on the results of surveys and socialization in group discussions, the objectives to be implemented in the economic empowerment of communities in Leduk, Jatiarjo and Dayurejo villages were: (1) economic improvement of farmer families; (2) increasing the work capacity and income of women's groups; (3) the development of environmentally sound forest agriculture, namely changes in the forest management system by the community from pure agricultural patterns to intercropping patterns. [51], explained, that a better family economic income was the fulfillment of basic living needs for family members.

The results of direct surveys in the communities of Leduk, Jatiarjo and Dayurejo village have 2 tribes namely Madura and Javanese, so the language of the day-to-day association uses the languages of Madura and Javanese. The majority of the population was moslem, some hamlets were adhering to the Kejawen's belief with holding strong Javanese traditional wisdom. Regional art that was still developing was Laro flying and Gandul flying, namely art that uses Ketipung, flying and Jidor instruments combined with Javanese verses and Islamic songs. The forms of social capital include human social relations in society, the growth of trust between fellow humans, adherence to the values of society, the level of concern between fellow humans, active involvement in social activities [54].

\subsubsection{Social capital}

Constraints on cultural and social conditions related to the empowerment of communities in Leduk, Jatiarjo and Dayurejo Villages are beginning to decline in values and norms as well as patterns of social interaction in regulating the daily lives of community members, because more and more industries were penetrating several neighboring villages some of the people who previously farmed live within the norms of mutual cooperation, especially women who switched professions as individualized factory workers, and there was not enough time to contract with the surrounding community.

The emergence of mutual trust between the community and Indonesian state forest company, so that forest management activities run independently without coordination. Adaptation of community-based forest management was also not optimal because of the weak socialization and exclusive approach. Indonesian state forest company's position was weak because people who have no land use the conditions of the reform era that often use coercion. Community empowerment requires the development of social capital on an ongoing basis, namely improving social relations, trust, and norms. The social relations in question include participation, cooperation, mutual care, and reciprocity. Trust and norms in social capital were considered as very important components because they support existing social relations. In this case it can be interpreted if there was no trust, then the existing social relations relationship cannot be said as social capital [2].

The successes that have been carried out in the social empowerment of communities in Leduk, Jatiarjo and Dayurejo villages include: (1) implementing forest resource conservation in accordance with the social characteristics of the forest communities; (2) increasing the social capital of forest village communities in accordance with local wisdom. Examples of activities that are routinely carried out every year were ritual social activities of thanksgiving, salvation of the community and preservation of springs in the villages of Dayurejo, Jatiarjo and Leduk. According to [43], revealing that communities around the forest still maintain elements of social capital such as the types of customs, culture, beliefs and rituals that were consistently maintained until now. The village community living around the forest has customary regulations in utilizing forest resources, these values or norms are mutually agreed and implemented, with the aim of forest resources remaining sustainable and they can continue to survive.

Based on the results of surveys and socialization in group discussions, the objectives to be implemented in community social empowerment in Leduk, Jatiarjo and Dayurejo Villages were: increasing the active role of community social capital such as social/work networks, level of trust between people, adherence to norms, concern for fellow human beings and families and involved in community social activities in forest village community institutions, then forest management will be more effective in supporting conservation based on ecology, economics and social. [21], explains that social capital was a value of trust that exists in a society.

\subsubsection{Local institution}

In the villages of Leduk, Jatiarjo and Dayurejo there were the forest village community institution, which actively manage 350 ha of forest in the Indonesian state forest company area of Arjuna mount. Forest management of the Leduk village area carried out by the forest village community institution of Bumi Lestari Mulyorejo, Jatiarjo village area 
carried out by the forest village community institution of Ngudi Lestari and the Dayurejo village area was carried out by the forest village community institution of Indrokilo Manunggal. As a legal entity, the forest village community institution has the authority to be able to cooperate between the community and Indonesian state forest company in forest management and preservation, so that in its implementation, forest management provisions are set forth in the articles of association and by-laws, and have received mutual consent from the community.

The constraints on the condition of forest village community institutions related to community empowerment in Leduk, Jatiarjo and Dayurejo villages were: (1) the capacity and role of forest village community institutions as forest managers was still not effective; (2) forest village community institutions did not have a more effective forest management program that supports conservation based on ecology, economics and social. The role of the forest village community institutions in forest management was important, this was explained by [15], that forest village community institutions was a community organization formally incorporated, as a place for all citizens to collaborate with the Indonesian state forest company, both parties can help each other, work together and have a high concern for the forest with the principle of partnership, so that strengthening forest village community institutions can support forest village community empowerment.

Some of the successes that have been carried out by forest village community institutions in empowering communities in Leduk, Jatiarjo and Dayurejo villages include: (1) forest village community institutions with the Indonesian state forest company was able to prevent forest resources from the threat of damage from looting activities by people living around the forest, this strategy in accordance with the regulations listed in government regulations number 72 of 2007; (2) forest village community institutions has conducted mapping of forest management rights in collaboration with the Indonesian state forest company, which has been legally stipulated in the forest village community institutions articles of association and By-Laws.

Based on the results of surveys and socialization in group discussions, the objectives to be implemented in the guidelines for developing village forest community institutions for community empowerment in Leduk, Jatiarjo and Dayurejo village were: (1) establishing plans, implementation and monitoring of forest village community institutions performance for community empowerment and revegetation of the Arjuna mountain; (2) evaluating community development programs through forest village organizations/ institutions/groups in relation to improving the welfare of the people of Leduk, Jatiarjo and Dayurejo villages; (3) strengthening institutional capacity of forest village community institutions of Bumi Lestari Mulyorejo in Leduk village, forest village community institutions of Ngudi Lestari Jatiarjo and forest village community institutions of Indrokilo Manunggal Dayurejo.

Procedure of forest village community activities in the forest management system with the community, with the achievement of forest village community development targets, namely: a) institutional strengthening and development, b) establishing forest plot planning in the lap of villages around the forest, c) stipulating requirements and indicators for resource management sustainable forest, d) monitoring, evaluation and corrective actions of the potential root causes of existing problems, and e) conducting performance evaluations for the next program [7].

\subsubsection{Infrastructure}

The constraints on the condition of facilities and infrastructure for empowering communities in Leduk, Jatiarjo and Dayurejo villages include: (1) places and equipment for improving business skills not available to the community; (2) technical guidance on business skills not available to the community; (3) village unit cooperatives were not yet available that can provide capital assistance to the community; (4) facilities and infrastructure were not available for forest conservation. Land preparation facilities and infrastructure to spur plant growth, reduce fire risk and minimize erosion, for example: plow and harrow mechanical devices, while chemicals were herbicides for rocky sloping land. Planting facilities and infrastructure such as plows, pick-up transporting plant seeds and seedling nursery locations. Weeding facilities and infrastructure, to mechanically use tractor tools, while manually using hoes, herbicides and tanks. Fertilizer facilities and infrastructure were hoes, fertilizers and tanks. [49], explained that the provision of basic facilities and infrastructure for community empowerment such as capital, guidance and equipment for inadequate business skills training, resulted in the community's capacity to develop and independently slow down, and eventually the empowerment of the community was lost.

Some of the successes that have been carried out regarding facilities and infrastructure for empowering communities in Leduk, Jatiarjo and Dayurejo villages were the availability of facilities and infrastructure for road access, transportation equipment, clean water, health and education facilities in Leduk, Jatiarjo and Dayurejo villages. [10], states that the facilities and infrastructure that were very important for the feasibility of human life were facilities 
and infrastructure, which include: (1) social services, such as schools, clinics, health centers, hospitals that were generally provided by the government; (2) social facilities (social facilities), such as places of worship, worship, meeting houses, sports fields, playgrounds/open spaces, shops, markets, stalls, sidewalks and so on; (3) environmental infrastructure including roads and bridges, clean water, electricity networks, telephone networks, dirty water networks and waste.

Based on the results of surveys and socialization in group discussions, the target to be implemented regarding the facilities and infrastructure for empowering communities in Leduk, Jatiarjo and Dayurejo villages was the development of environmental facilities and infrastructure as a form of increasing community empowerment, attention, support, guidance and of course assistance from various related parties, namely the government of Prigen subdistrict and the Leduk, Jatiarjo and Dayurejo villages. Furthermore, if there were problems regarding the implementation of the community empowerment program, a solution can be found. Therefore, it was good to develop environmental infrastructure as a manifestation of the implementation of the community empowerment program that needs continuity or sustainability so that the community can be more smooth and comfortable in carrying out daily activities.

\subsection{Soil and geographical conditions}

\subsubsection{Land slope}

The problem of the slope of the area around the spring water source for revegetation of Arjuna mount forest was the steep slope of $15^{\mathrm{O}}-<30^{\mathrm{O}}$, the condition states that the area was sloping and hilly. Constraints that exist were erosion and critical land and arid, because plants were difficult to grow in locations where there was no fertile soil. [3], explains that the slope factor will mainly affect the erosion that occurs, the greater the percentage of slope on a slope will provide erosivity to the greater rainfall. So that various fertility materials and soil physical properties will be affected by the release that occurs on the surface.

Some of the successes that had been carried out regarding the condition of the slope of the area around the spring for the revegetation of Arjuna mount forests were planting 19500 trees, in the area around the Lajer, Dawuan, Sumberkuning and Watupereng springs, with a total area of forest revegetation of 93 hectares, starting in 2014. Revegetation of forests in the area around the spring in accordance with PP No. 43/2008, that revegetation was carried out comprehensively in groundwater basins that include recharge areas and groundwater release areas, through (1) protection and preservation of ground water; (2) preservation of ground water; and (3) quality management and control of groundwater pollution [52].

Based on survey results and socialization in group discussions, the target to be carried out related to the slope of the land $15^{\mathrm{O}}-<30^{\mathrm{O}}$ in the area around the spring for revegetation of Arjuna mount forest was to maintain the condition of the land slope without erosion, by planting erosion control trees. The characteristics of erosion control trees were intensive roots with long taproots, and grow fast at a young age. Tree species that meet these requirements include: waru gunung (Hibicus macrophyllus), marmojo (Indigofera galegoides), gianti (Sesbania sesban), hapaan (Flemingia congesta), kemlandingan (Leucaena glauca) and johar (Cassia siamea), gianti (Sesbania sesban), mindi plants (Melia azedarach), balsa (Ochroma bicolor), wungu (Lagerstroemia speciosa), alingsem (Homalium tomentosum), eucalyps (Eucalyptus alba), laban (Vitex pubescens), candlenut (Aleurites moluccana), and damar (Agathis dath).

Maintain the condition of the slope of the land so that it did not collapse, by planting landslide control trees, with the characteristics: rooted less intensively and taproots grow faster, and stem growth less quickly in young. Tree species that meet the requirements include: tekik (Albizzia lebeck), pilang (Acacia leucophlocea), asem (Tamaridus indica), tajuman (Bauhinia malabarica), trengguli (Cassia fistula), sono keling (Dalbergia latifolia), sono sisso (Sono sisso), tajuman (Bauhinia malabarica), trengguli (Cassia fistula), sono kembang (Pterocarpus indicus), mahogany (Swietenia macrophylla), rengas (Gluta rengas), kesambi (Chleichera oleosa) and jati (Tectona grandis) [25].

\subsubsection{Soil depth}

The problem of effective soil depth conditions around the spring water for revegetation of Arjuna mount forest was that the surface condition of the soil was reduced due to erosion during the rainy season, and the soil depth of the spring area was reduced. Observation of effective soil depth in the area around the source of the medium inlet, that was soil depth of 50-90 cm. [29], explained that the effective depth was the depth of the soil to the extent that the soil can be overgrown with roots, storing enough water and nutrients, generally limited by the presence of gravel and parent material or other hard layers, so that no longer can be penetrated by plant roots. The effective soil depth for plants was 
reduced, so the effectiveness of soil fertility was low, and of course this requires a lot of input, so the cost of revegetation of the forest becomes more expensive. Forest revegetation was an important thing to know the characteristics and quality of the soil [33], so that the best alternative management could be given [4].

Some of the successes that had been carried out related to preventing erosion in the area around the spring for the revegetation of Arjuna mount forests were planting, maintaining and fertilizing 19500 trees, in the area around the Lajer, Dawuan, Sumberkuning and Watupereng springs. The 32 planting activities, treatments and fertilizers were carried out by 32 forest farmers from the villages of Leduk, Jatiarjo and Dayurejo, Prigen Pasuruan District, with the duration of the activity being 3 years. Planting trees improves the vegetation function of the area around a spring that is the ability of the soil to absorb rainwater, maintain or increase the infiltration rate, and demonstrate the ability to retain water or water retention capacity, and prevent land erosion [44]. Based on the results of surveys and socialization in group discussions, the target to be carried out in relation to preventing erosion in the area around the spring for the revegetation of Arjuna mount forest was to plant endemic species, plants for springs and fruit for the revegetation program in $2019-2021$.

\subsection{Forest revegetation}

\subsubsection{Plant species}

Constraints of plant species conditions for revegetation of Arjuna mount forest were endemic plant species and spring water vegetation. [18], explained that the main indicator of forest revegetation through the restoration of degraded ecosystems was plant species. Selection of tree species to be planted was determined by three factors, namely: (1) the importance of natural species for revegetation, (2) the availability of seedlings and propagation, and (3) the location of revegetation to be carried out [9].

Some of the successes that have been carried out in relation to Arjuna mount forest revegetation plant species preservation of the Lajer, Dawuan, Sumberkuning and Watupereng springs were the first stage revegetation activities at the Lajer spring with an area of 10 hectares, the number of plants 3000 trees, with a breakdown of plant species: 1000 bamboo (Dendrocalamus asper), 600 candlenut (Aleurites moluccana), 400 kluwek (Pangium edule), 300 kluweh (Artocarpus communis), 100 banyan (Ficus benyamina), 500 durian (Durio sp) and 100 elo (Ficus glomerata).

The second stage of revegetation of Arjuna mount forest in the area around the Dawuan spring was 15 hectares, the number of plants was 1500 trees, with details of plant species including petung bamboo (Dendroca-lamus asper) 300 trees, candlenut (Aleurities mollucana) 500 trees, banyan (Ficus benyamina) 50 trees, bendo (Artocarpus elasticus) 450 and ivory 200 trees.

The third stage of revegetation of Arjuna mount forest in the area around the Sumberkuning springs, the area of revegetation area of 25 hectares, the number of plants of 5000 trees, with the details of the types of plants including mountain spruce (Casuarina junghuniana) 2000 trees, 300 trees kesek 300 trees, petung bamboo (Dendrocalamus asper) 500 trees, tutup (Mallocus moluccana) 200 trees, mlandingan (Leucaena glauca) 500 trees, kaliandra (Calliandra calothyrsus) 1000 trees and gmelina (Gmelina arbora) 500 trees.

Revegetation of the fourth stage of Arjuna mount forest in the area around the Watupereng springs, the area of revegetation area of 46 hectares, the number of plants 8000 trees, with details of the types of plants including bamboo petung (Dendrocalamus asper) 1300 trees, banyan (Ficus sp) 500 trees, kluweh (Artocarpus communis) 180 trees, candlenut (Aleurities mollucana) 450 trees, matoa (Pometia pinnata) 820 trees, cloves (Syzygium aromaticum) 850 trees, soursop (Annona muricata) 800 trees, avocado (Persea americana) 1000 trees, durian (Durio sp) ) 1200 trees and coffee (Coffea sp) 900 trees.

Based on the results of surveys and socialization in group discussions, the targets to be carried out related to the revegetation plant species of Arjuna mount forest preservation in 3 springs are springs that were Curahtangkil Dayurejo village), Puthukbunder Jatiarjo village and Talangwatu Leduk village, with a total revegetation area of 90 hectares, the number of plants 18000 trees, with details of the types of plants include:

1) Endemic plant species, namely: bendo (Artocarpus elasticus) 1000 trees, kluwek (Pangium edule) 1000 trees, breadfruit (Artocarpus altilis) 1000 trees, candlenut (Aleurites mollucanus) 1000 trees, gondang (Ficus variegate) 1000 trees

2) Species of spring water plants, namely: petung bamboo (Dendrocalamus $s p$ ) 2000 trees, aren (Arenga pinnata) 1000 trees, banyan (Ficus benyamina) 2000 trees, epek (Ficus elastica) 1000 trees 
3) Fruit plant species, namely: avocado (Persea americana) 1500 trees, oranges (Citrus sp) 1000 trees, coffee (Coffea sp) 1000 trees, soursop (Annona muricata) 1500 trees, durian (Durio sp) 1000 trees and guava (Psidium guajava) 1000 trees.

\subsubsection{Plant Nursery}

The obstacle of plant nursery conditions for revegetation of Arjuna mount forest was that the quality of seedlings was not the same, so plants die in the first month of planting, plant seeds were unable to adapt to the environmental conditions in which they grow. In the first phase revegetation at the Lajer spring with an area of 10 hectares, the number of plants was 3000 trees, for 3 years the number of dead trees was 801 trees. In the second phase revegetation in the area around the Dawuan spring area of 15 hectares, the number of plants was 1500 trees, the number of trees that died over 3 years was 325 trees. In the third stage revegetation in the area around the Sumberkuning spring, the area of the revegetation area was 25 hectares, the number of plants was 5,000 trees, the number of trees that have died for 3 years was 697. In the fourth stage revegetation of Arjuna mount forest in the area around the Watupereng spring, revegetation area of 46 hectares, the number of plants 8000 trees, the number of trees that die during 1 year was 42 trees.

Provision of quality plant seedlings could be done through seedbed, nursery first in the nursery before planting in the field intended to get good seedlings in terms of quantity and quality and could be planted at the right time too [38]. High-quality plant seeds could only be obtained from seed sources that were built from the best selected individuals. It was expected that with the use of quality seeds, crop productivity will increase. The seed source of forest plants was an influential factor in improving the appearance of forest stands [13].

Some of the successes that have been carried out related to plant nurseries for revegetation of Arjuna mount forest were the availability of plant seeds for revegetation in the area around the Lajer, Dawuan, Sumberkuning and Watupereng springs with an area of 90 hectares, and the number of plants of 17500 trees. The height of the initial tree seedlings planted was at least 2 meters. The price of seeds per tree with a height of 2 meters was IDR 18,000. Plant seeds that die due to disease pests or damaged by porcupine pests, then immediately replaced with other plants that were able to live with the environmental conditions in which they grow. Good quality disease-resistant seeds were affected by a variety of factors including: tree age, tree size, crowns, genetic factors, climate, soil fertility, stand density, pests and diseases, fruit maturity and handling processes ranging from downloading in the field to storage and distribution [36].

Based on the results of the survey and socialization in the group discussion, the targets to be carried out in relation to the nursery of Arjuna mount forest revegetation were (1) providing quality seedlings from 18,000 trees; (2) tree seedlings consist of endemic plants, springs and fruit plants; (3) height of tree seedlings planted at least 2 meters.

\subsubsection{Fertilizing}

The obstacle of fertilizing plants for revegetation of Arjuna mount forest was the type of fertilizer that was given to plants that was not in accordance with the changing soil nutrient content, this was due to the loss of nutrients from forest damage or erosion. Fertilization was done if there was a lack of nutrients or growth was slow [11].

Fertilizers given to plants were organic fertilizer and inorganic fertilizer. Provision of organic fertilizer can improve soil structure, increase soil absorption of water, improve living conditions of soil microbes and as a food source for plants. Application of inorganic fertilizers could stimulate overall plant growth and important assistance in the formation of green leaves [16].

Some of the successes that had been carried out related to plant fertilization for revegetation of Arjuna mount forest are providing nitrogen, phosphor and potassium organic fertilizer and inorganic manure for 17500 trees 3 times in 1 year for 3 years of care by small holder farmers. According to [36], fertilization was a very important way to improve crop productivity and soil quality. The use of organic fertilizers and inorganic fertilizers was the right way, not only to produce crop productivity but can maintain intensive plant production stability.

Based on the results of surveys and socialization in group discussions, the target to be carried out by plant fertilization in the advanced forest revegetation program was to provide nitrogen, phosphor and potassium organic fertilizer and inorganic manure for 18000 trees 3 times in 1 year for 3 years of care by the cultivating farmers.

\subsubsection{Planting}

The obstacle of planting trees for revegetation of Arjuna mount forest was the size and the distance between plants was a factor that must be considered for plant growth, because the success of forest revegetation technically according 
to [31] was the regulation of light (light control) and selection of plant species. The width and distance between revegetation plants of Arjuna mount forest towards the preservation of Lajer, Dawuan, Sumberkuning and Watupereng springs were 10 meters x 10 meters (200 trees/ha).

According to the Minister of Forestry Regulation Number P. 70/Forester Minister-II/2008 about technical guidelines for forest and land rehabilitation, explained in chapter IV. point 2. In general the number and distance of planting that was often used for revegetation was divided into several groups, namely: (1) spacing of 5 meters x 5 meters (400 trees/ha); (2) spacing of 5 meters x 2.5 meters ( 800 trees/ ha); (3) spacing of 3 meters x 3 meters (1,110 trees/ha); (4) spacing of 3 meters x 2 meters (1,666 trees/ha); plant spacing of 3 meters x 1 meter (3,333 trees/ha).

Some of the successes that had been carried out related to planting for revegetation of Arjuna's mount forests were the implementation of revegetation around the area of the Lajer, Dawuan, Sumberkuning and Watupereng springs, a total area of 93 hectares and a total of 19,500 trees. This revegetation program was carried out by PT. Sorini Agro Asia Corporindo (Cargill) in collaboration with the Kaliandra Foundation, Cempaka and the people of the villages of Leduk, Jatiarjo and Dayurejo.

Table 3. Arjuna mount forest revegetation to the springs preservation period 2014-2018

\begin{tabular}{ccccc}
\hline No & Springs location & Number of trees & $\begin{array}{c}\text { Area } \\
\text { (hectares) }\end{array}$ & $\begin{array}{c}\text { the percentage of trees } \\
\text { living }\end{array}$ \\
\hline 1 & Lajer - Arjuna mount & 3000 & 10 & $94 \%$ \\
2 & Dawuan - Arjuna mount & 1500 & 5 & $92 \%$ \\
3 & Sumber Kuning - Arjuna mount & 5000 & 25 & $86 \%$ \\
4 & Watu Pereng - Arjuna mount & 6000 & 34 & $99 \%$ \\
5 & Watu Pereng - Arjuna mount & 4000 & 19 & $99 \%$ \\
\hline & & 19500 & 93 & \\
\hline
\end{tabular}

Source: [39]

\subsubsection{Revegetation of forests I in 2014 Lajer springs area}

The first year of forest revegetation program began planting on February 27, 2014, with the purpose of improving the vegetation of around area of Lajer springs, by planting and maintaining plants for 3 years to keep the volume of water flowing and increasing, and preventing landslides and floods. Guidelines for revegetation of the Lajer spring water source area were government regulations number 43 of 2008, that revegetation was carried out thoroughly in groundwater basins which include recharge areas and groundwater discharge areas, through (1) protection and preservation of groundwater; (2) preservation of ground water; and (3) quality management and control of groundwater pollution. The decrease in spring discharge was caused by a reduction in protected areas or water catchment areas due to illegal deforestation and land conversion that results in critical land occurrence and a decline in the quality of water catchment areas [52]. The result of revegetation phase I was to increase the vegetation cover of 10 hectares of land in the area around Lajer springs, with a total of 3000 trees. 3000 species of plants include: 1000 bamboo (Dendrocalamus asper), 600 pecan (Aleurites moluccana), 400 kluwek (Pangium edule), 300 kluweh (Artocarpus communis), 100 banyan (Ficus benyamina), 500 durian (Durio zibethinus) and 100 elo (Ficus glomerata). Intensive plant maintenance was carried out for 3 years, with 5 nurse farmers from the community around the forest.

Based on verification results in each year shows that in the first year period of 2014 the percentage of living trees was $98 \%$, in the second year of 2015 the percentage of living trees was $96 \%$ and in the third year 2016 the percentage of trees the life was $94 \%$. Some factors that influence the percentage of the number of trees that live relatively stable are nurse farmers who directly replace dead plants with other plants, even though the plant species are different, so the number of trees was relatively close to a percentage. While other technical factors that affect the percentage of living trees are relatively stable, among others: (1) treatment of grass cleansing on plants, (2) weeding plants, (3) giving water to plants in the dry season, (3) making bulkhead burn, during the dry season, (4) routine evaluation of plant maintenance from farmers to NGOs, forest village community institutions, companies and the government every month, (5) corporate social responsibility programs for economic empowerment for nurse farmers. The results of verification for 3 years showed that the highest number of plant deaths occurred in durian plants reaching $98.8 \%$ (the initial number of plants 500 trees, which lived were 6 trees), the cause of death of durian trees (Durio zibethius) was eating animal Porcupines especially new stems who sprouted, so that the corrective action was to replace the types of plants that are resistant to porcupine pests such as jackfruit, mahogany, sengon buto, srampang balong and segawe plants. The dry 
season factor during August-November 2014, with temperatures above normal temperature (temperature $37-39^{\circ} \mathrm{C}$ ), has the potential to cause forest fires.

\subsubsection{Forest revegetation II year 2015 Dawuan springs source area}

Based on the results of verification on February 23, 2015 shows that the area of forest rehabilitation in the second period in the area around the Dawuan spring was 15 hectares, with the number of plants was 1500 trees, data on types of plants include petung bamboo Petung (Dendroca-lamus asper) 300 trees, candlenut (Aleurities mollucana) 500 trees, banyan (Ficus benyamina) 50 trees, bendo (Artocarpus elasticus) 450 trees and Ivory tree 200 trees. The number of nurse farmers who directly carry out and care for plants was 3 people, each of whom receives 6 goats breeding assistance. Plant maintenance was scheduled every 1 week with the main goal of caring for and maintaining plant growth. 3 months after the initial planting, in April 2015 the nurse farmers carried out fertilization and planting dead plants.

Based on the results of verification at the planting location around the Dawuan spring, it showed that up to May 30, 2015 the number of dead plants was 103 plants, and the nurse farmers immediately replaced with 140 new plants for planting. The total number of plants from verification in December 2016 was 1537 trees. Some types of plant replacement for revegetation include: spathodea (Spathodea campanulata) 20 trees, mahogany (Sweetenia mahagoni) 8 trees, srikaya (Annona squamosa) and jackfruit (Artocarpus heterophyllus) 5 trees. [16], states that plant growth was influenced by soil factors, climate, microorganisms, competition by other organisms, and is also influenced by available organic substances, humidity and sunlight. Based on the results of the implementation of this second rehabilitation program, researchers measured and verified that Petung bamboo plants were very strong and resistant to be planted in critical areas and with little water, and able to hold water when the rainy season occurs.

Based on the results of observations and measurements show that the number of plant deaths in the second stage rehabilitation program in the Dawuan springs, verification during the first year of 2015 the number of living trees was 1442 trees (96\%), in the second year 2016 the number of living trees was 1404 trees (94\%), and in the third year verification in April 2017 the number of trees that lived to be 1380 trees or $92 \%$ of the initial number of trees planted as many as 1500 trees.

\subsubsection{Forest revegetation III year 2016 Sumberkuning springs area}

The third stage of the forest revegetation program was held on March 29, 2016 with a location in the Sumberkuning springs area. The revegetation area was 25 hectares with a total of 5000 trees, with plants including mountain cypress (Casuarina junghuniana) 2000 trees, kesek 300 trees, petung bamboo (Dendrocalamus asper) 500 trees, tutup tree (Mallocus moluccana) 200 trees, mlandingan (Leucaena glauca) 500 trees, calliandra (Calliandra calothyrsus) 1000 trees and gmelina (Gmelina arbora) 500 trees. Sumberkuning spring was included in the area of Jatiarjo Village, Prigen Subdistrict, Pasuruan Regency, with different conditions compared to phase 1 and 2 revegetation activities (Lajer and Dawuan springs). The Sumberkuning spring was located at an altitude of 2,427 meters above sea level, and the forest area was under the management of the East Java Province forestry service. Community forest park of Raden Soerjo. The area was included in the conservation forest status, where there was a community allowed to do forest conservation but cannot take anything inside the forest area. The selection of forest rehabilitation sites in the Sumberkuning area was to protect upstream springs, which have been damaged by forest fires in November 2015, so that these forests need to be treated and protected from forest fires. If the water discharge in the area of the spring was reduced, then it has an impact on a number of springs under it.

Based on the results of verification on March 29, 2016, the third period of forest revegetation area in Sumberkuning springs area were 25 hectares, with a total of 5000 trees. The results of planting verification for 2 years showed that in the first year the number of living plants was 4485 trees (90\%) and 515 trees died. In the second year of verification in April 2017, the number of living plants was 4303 trees (86\%) and the number of plants that died from 2017 to April 2017 was 697. The number of nurse farmers who were directly involved in the management of Sumberkuning springs forest rehabilitation in the program community empowerment was 5 people.

\subsubsection{Forest revegetation IV year 2017 Watu Pereng springs area}

The fourth stage of the forest rehabilitation program was carried out in the springs area of Watupereng, the Gumandar Sub-watershed (watershed) in Jatiarjo Village, Prigen District, Pasuruan Regency on February 21, 2017, 
with the theme "Caring for the Forest". The area of the forest rehabilitation area was 46 hectares, with the number of trees as many as 8,000 trees, this rehabilitation area was included in the protected forest of the Indonesian state forest company of west Lawang in plot 35. The types of trees planted include petung (Dendrocalamus asper), banyan (Ficus $s p$ ), kluweh (Artocarpus communis), pecan (Ale mollucana), matoa (Pometia pinnata), clove (Syzygium aromaticum), soursop (Annona muricata), avocado (Persea americana), durian (Durio Zibethinus) and coffee (Coffea canephora Pierre). By implementing this revegation program, Sorini Cargill has been conserving 4 springs (Lajer, Dawuan, Sumberkuning and Watupereng), with a total area of 83 hectares, and 17,500 trees planted and involving 28 forest nurse farmers in the form of a program to empower communities around the forest Through this sustainable forest rehabilitation program, the company was committed to carrying out the obligation to improve the rainwater catchment area that was upstream for water needs for all communities in Pasuruan Regency. The results of tree planting verification show that up to April 2017 the number of living trees was 7958 trees (99\%).

Based on survey results and socialization in group discussions, the target to be carried out with planting for the forest revegetation program was to carry out a revegetation program for the second period of 2019-2020 in the area around of springs the Dayurejo Sumbertangkil, Jatiarjo Puthukbunder and Leduk Talangwatu. The extent of revegetation was 90 hectares, the number of plants was 18000 trees. This revegetation program was carried out by PT. Sorini Agro Asia Corporindo, in collaboration with the Cempaka foundation, Indonesia state forest company, the Pasuruan Regency Environmental Service and the villagers of Dayurejo, Jatiarjo and Leduk.

Some tree species planted include: (1) endemic plant species, namely: bendo (Artocarpus elasticus) 1000 trees, kluwek (Pangium edule) 1000 trees, breadfruit (Artocarpus altilis) 1000 trees, candlenut (Aleurites mollucanus) 1000 trees, gondang (Ficus variegate) 1000 trees; (2) springs plant species, namely: petung bamboo (Dendrocalamus sp) 2000 trees, sugar palm (Arenga pinnata) 1000 trees, banyan (Ficus benyamina) 2000 trees, epek (Ficus elastica) 1000 trees; (3) fruit plant species, namely: avocado (Persea americana) 1500 trees, orange (Citrus sp) 1000 trees, coffee (Coffea sp) 1000 trees, soursop (Annona muricata) 1500 trees, durian (Durio sp) 1000 trees and guava (Psidium guajava) 1000 trees.

The purpose of this revegetation program was to improve the condition of forest cover in the area around 3 springs, covering 90 hectares on the slopes of Arjuna and Welirang mount through the concept of enrichment of productive plants that can be utilized by the community to improve the welfare of forest farmers. The location of the planting was in the area around the Dayurejo Sumbertangkil springs, Jatiarjo Puthukbunder and Leduk Talangwatu, all three villages are included in the Kedunglarangan Sub-watershed, which was part of the catchment area as an underground water source of PT. Sorini Agro Asia Corporindo.

\subsubsection{Plant care}

The obstacle of tree care for revegetation of Arjuna's mount forest was the growth of weeds or weeds around the plants, replacing and replacing dead plants, due to pests and plant diseases and damaged by animals. According to [37], care plays an important role in achieving successful planting. Maintenance activities include weeding from weeds, pests or the like that were wrapped around the plant, and from pioneers that rival the plants, and replanting if any plants die. In the treatment of plants, monitoring activities could also be carried out which includes verification of growth (plant survival), growth performance (growth performance), increment (growth increments) including height, diameter, volume and attack of pests and diseases.

Some of the successes of plant maintenance that had been carried out for revegetation of Arjuna mount forest were funding of plant care for 5 nurse farmers for 3 years on 10 hectares of land vegetation in the area around the Lajer spring, the number of plants 3000 trees, with plant species including 1000 bamboo (Dendrocalamus asper), 600 candlenut (Aleurites moluccana), 400 kluwek (Pangium edule), 300 kluweh (Artocarpus communis), 100 banyan (Ficus benyamina), 500 durian (Durio sp) and 100 elo (Ficus glomerata).

Plant care financing for 3 nurse farmers for 3 years in a 5 hectare vegetation area around the Dawuan springs, the number of plants was 1500 trees, plant species data including petung bamboo (Dendroca-lamus asper) 300 trees, candlenut (Aleurities mollucana) 500 trees, banyan (Ficus benyamina) 50 trees, bendo (Artocarpus elasticus) 450 and ivory 200 trees.

Funding for plant maintenance in the Sumberkuning springs area. Revegetation area was 25 hectares with a total of 5000 trees, with types of plants including mountain spruce (Casuarina junghuniana) 2000 trees, 300 trees squared, petung bamboo (Dendrocalamus asper) 500 trees, cover (Mallocus moluccana) 200 trees, mlandingan ( Leucaena glauca) 500 trees, kaliandra (Calliandra calothyrsus) 1000 trees and gmelina (Gmelina arbora) 500 trees. 
Plant care funding for 28 nurse farmers for 3 years in a 46 hectare vegetation area around the Watupereng springs, a total of 8000 trees, with types of plants including bamboo petung (Dendrocalamus asper) 1300 trees, banyan (Ficus sp) 500 trees, kluweh (Artocarpus communis) 180 trees, candlenut (Aleurities mollucana) 450 trees, matoa (Pometia pinnata) 820 trees, tutup plant (Syzygium aromaticum) 850 trees, soursop (Annona muricata) 800 trees, avocado (Persea americana) 1000 trees, durian (Durio sp) 1200 trees and coffee (Coffea sp) 900 trees.

Based on survey results and socialization in group discussion, the target to be carried out with plant care in the revegetation of Arjuna mount forest in the second period of 2019-2020 was plant care financing for 32 nurse farmers for 3 years on vegetation in an area of 90 hectares in the area around the source of the Dayurejo Curahtangkil springs, Jatiarjo Puthukbunder springs and Ledug Talangwatu springs, the number of plants was 18000 trees. Cempaka foundation and nurse farmers are responsible for maintaining crop growth rates up to 3 years by $90 \%$ of the trees planted are still alive and growing.

\subsection{Plants vegetation profile}

\subsubsection{Vegetation stratification}

Some of the obstacles faced in the stratification of tree vegetation in Arjuna mount forest were that the growth of tall trees was not the same, so stratification or coating of tree canopy had not been formed. Stratification formed from canopy arrangements of trees can become forest vegetation for water absorption. In forest ecosystems, stratification was formed from the canopy arrangement of several plants, in the form of a vertical direction, this condition occurs because of the composition of dominant, codominant, intermediate, depressed, and lower tree class plants [31].

Some of the successes of tree stratification improvements that have been done carried out for the Arjuna mountain forest revegetation were carrying out planting with the same type and height of trees, and replacing dead plants with new plants whose height was the same as plants that have grown long. In 2014 revegetation in the area of Lajer's spring area of 10 hectares, 700 trees had been added to replace dead plants. The percentage of live plants after 3 years of monitoring was 94\%, meaning that from 3000 trees planted in 2014, in the third year of monitoring, there were 2016 plants that lived as many as 2873 trees.

In 2015 revegetation in the Dawuan springs area of 5 hectares, 205 trees were added as a replacement for dead plants. The percentage of live plants after 3 years of monitoring was $92 \%$, meaning that out of 1500 trees planted in 2015 , in the third year of monitoring, there were 1380 trees that live.

In 2016 revegetation in the Sumberkuning springs area of 25 hectares, there were no additional plants for 3 years of monitoring and maintenance. The percentage of live plants after 3 years of monitoring was $86 \%$, meaning that of the 5000 trees planted in 2016, in the third year of monitoring, 2018 plants lived as many as 4485 trees.

In 2017 and 2018 revegetation in the 53 hectare Watupereng spring area, there were no additional plants for 3 years of monitoring and maintenance. The percentage of live plants after 3 years of monitoring was $99 \%$, meaning that from 8000 trees planted at the beginning of the planting year, in the first year of monitoring, that was December 2018, 7958 trees live.

Based on the survey results and socialization in the group discussion, the objectives to be carried out with the maintenance and improvement of plant stratification for revegetation of the Arjuna mountain forest for the second period of 2019-2020 were tree planting according to the height of the plant location, requirements for plant species, minimum plant height, plant species endemic and spring water plant species.

\subsubsection{Bird wealth}

Some of the obstacles faced in the bird wealth preservation of the Arjuna mount forest area were the occurrence of poaching, and forest fires in every dry season in the area around the source of water, this causes the number of bird species such as finches, green cucak, parrots, trocok and many pigeons reduced and difficult to obtain. Healthy forest was a conservation area to preserve various species of birds. Forests were a source of various types of natural foods for all types of animals including the types of fruit-eating birds. Revegetation of fruit trees also supports the provision of food sources for various types of fruit-eating birds, therefore the occurrence of forest fires will have an impact on the preservation of biodiversity [30].

Some of the successes in improving the sustainability of bird wealth in the Arjuna mount forest area were (1) planting fruit trees, as a food source for various fruit-eating birds; (2) carry out plant maintenance to maintain the preservation of biodiversity. There were mutually beneficial relationships and interactions between birds and plants. 
Diaspora of plants will be spread far from its parent plants, because of the help of birds in its spread. Plant seeds will also germinate faster because the skin and flesh of the fruit have been destroyed when passing through the digestion of birds. Birds also benefit from these interactions especially for fruit-eating or nectar birds that use plant parts as food sources [35]. Based on the results of the survey and outreach in group discussions, the objectives to be implemented to improve the sustainability of bird wealth in the Arjuna mountain area in the second period of 2019-2020 were (1) planting fruit trees, as a food source for various fruit-eating birds. The types of fruit trees planted include avocados (Persea americana) with 1500 trees; oranges (Citrus sp) number of 1000 trees; coffee (Coffea sp) with 1000 trees; soursop (Annona muricata) with 1500 trees; durian (Durio sp) with 1000 trees and guava (Psidium guajava) with 1000 trees. (2) releasing various types of fruit-eating birds in the revegetation area of Arjuna mount forest.

\subsubsection{Taxonomy wealth}

Table 4. Tree planting of the Arjuna mount forest for the 2014-2018 period

\begin{tabular}{|c|c|c|c|c|}
\hline NO & Year & Revegetation location & $\begin{array}{c}\text { Nmber of } \\
\text { trees }\end{array}$ & $\begin{array}{c}\text { Area } \\
\text { (hectar) }\end{array}$ \\
\hline 1 & 2014 & Lajer - Arjuna mount & 3000 & 10 \\
\hline 2 & 2015 & Dawuan - Arjuna mount & 1500 & 5 \\
\hline 3 & 2016 & Sumber Kuning - Arjuna mount & 5000 & 25 \\
\hline 4 & 2017 & Watu Pereng - Arjuna mount & 6000 & 34 \\
\hline 5 & 2018 & Watu Pereng - Arjuna mount & 4000 & 19 \\
\hline \multicolumn{2}{|l}{} & & 19500 & 93 \\
\hline
\end{tabular}

Source: [39]

Some of the obstacles faced in the preservation of the taxonomic wealth of the Arjuna mount forest were (1) the change in the function of protected forests into production forests and tourist destinations, low plant biodiversity production forests; (2) forest fires in the dry season, plant pests and diseases, and damage to plants by animals and humans reducing biodiversity; (3) the types of plants planted were not in accordance with the ecosystem of forest heights. The higher the level of taxon wealth or forest biodiversity, the higher the level of health and sustainability of the forest, because the higher the biodiversity the more complex the ecological processes that occur so that the level of stability was high [32]. [23], explained that the analysis of species biodiversity measurement requires two indicator data, namely (1) data on the number of species richness and (2) density or abundance.

Some of the successes in improving the sustainability of the wealth of the taxon of the Arjuna mount forest were the planting of various species of trees, from endemic species of plants, springs and fruits. The total number of plants was 19500 trees, with an area of revegetation of 93 hectares, in the area around the springs of Lajer, Dawuan, Sumberkuning and Watupereng, which were carried out for 5 years as explained in Table 4.

Planting 3000 trees in the Lajer springs area, with plants including 1000 bamboo (Dendrocalamus asper), 600 candlenuts (Aleurites moluccana), 400 kluwek (Pangium edule), 300 kluweh (Artocarpus communis), 100 banyans (Ficus benyamina), 500 durian (Durio sp) and 100 elo (Ficus glomerata).

Planting 1500 trees in the Dawuan spring area, with types of plants including petung bamboo petung (Dendrocalamus asper) 300 trees, candlenut (Aleurities mollucana) 500 trees, banyan (Ficus benyamina) 50 trees, bendo (Artocarpus elasticus) 450 and ivory plant 200 trees.

Planting 5000 trees in the Sumber Kuning spring area, with plants including mountain cypress (Casuarina junghuniana) 2000 trees, swirling 300 trees, petung bamboo (Dendrocalamus asper) 500 trees, cap (Mallocus moluccana) 200 trees, mlandingan (Leucaena glauca) ) 500 trees, kaliandra (Calliandra calothyrsus) 1000 trees and gmelina (Gmelina arbora) 500 trees.

Planting 8000 trees in the Watu Pereng spring area, with plant species including petung bamboo (Dendrocalamus asper) 1300 trees, banyan (Ficus sp) 500 trees, kluweh (Artocarpus communis) 180 trees, candlenuts (Aleurities mollucana) 450 trees, matoa (Pometia pinnata) 820 trees, cloves (Syzygium aromaticum) 850 trees, soursop (Annona muricata) 800 trees, avocado (Persea americana) 1000 trees, durian (Durio sp) 1200 trees and coffee (Coffea sp) 900 trees. 
Based on the survey results and socialization in group discussions, the target to be carried out to improve the preservation of the taxon wealth of Arjuna mount forest in the second period of 2019-2020 was the planting of 18,000 trees in the area of Curahtangkil springs-Dayurejo, Puthukbunder-Jatiarjo and Talangwatu-Leduk. Some tree species planted include: (1) endemic plant species, namely: bendo (Artocarpus elasticus) 1000 trees, kluwek (Pangium edule) 1000 trees, breadfruit (Artocarpus altilis) 1000 trees, candlenut (Aleurites mollucanus) 1000 trees, gondang (Pangium edule) 1000 trees, breadfruit (Artocarpus altilis) 1000 trees, candlenut (Aleurites mollucanus) 1000 trees, gondang (Ficus variegate) 1000 trees; (2) springs plant species, namely: petung bamboo (Dendrocalamus sp) 2000 trees, sugar palm (Arenga pinnata) 1000 trees, banyan (Ficus benyamina) 2000 trees, epek (Ficus elastica) 1000 trees; (3) fruit plant species, namely: avocado (Persea americana) 1500 trees, oranges (Citrus sp) 1000 trees, coffee (Coffea sp) 1000 trees, soursop (Annona muricata) 1500 trees, durian (Durio sp) 1000 trees and guava (Psidium guajava) 1000 trees. One biological component in the forest was a plant. If biodiversity refers to all living things in the forest, the diversity of trees was all types of trees that were in the forest. Natural forests tend to naturally have various types of plants. Biodiversity was used in the assessment of forest health indicators caused by three things: (1) sensitive to change; (2) ecological system indicators; and (3) spatial, temporal and trophic heterogeneity. In the assessment of forest health, parameters that could be used for biodiversity indicators were the index of diversity, the index of similarity, the index of diversity, and the index of species evenness [42].

\subsubsection{Plant density}

Some of the obstacles faced in the Arjuna mount forest plants density were the height of the initial plant of 1.5 meters, and the size of the width and distance between plants was 10 meters x 10 meters ( 200 trees/ha). The results of verification after 3 years of plant maintenance showed that tree stands were rare, plant canopy density was less than $40 \%$ of canopy closure. The size of plant canopy density was divided into 3 canopy density classes (Indriyanto, 2006), namely: (1) meeting stands, if there are more than 70\% canopy closure; (2) enough stands, if there are 40-70\% crown cover and (3) rare stands, if there was less than $40 \%$ canopy cover.

Some of the successes in improving the density of Arjuna mount forest plants were (1) replacing damaged and dead plants with new plants with the same tree height, for 3 years of maintenance; (2) doing maintenance includes cleaning plants from grass, weeding plants, making firebreaks during the dry season, preventing plant diseases, fertilizing and administering drugs, weeding from weeds, giving water during the dry season and protecting plants from natural and human damage. Conduct joint monitoring, directly at the planting location every 4 months, and make a report as a basis for corrective and preventive actions. Figure 6. shows the plants density in the spring area of Lajer, Dawuan and Watupereng.

Plant density was a value that shows the number of species of plants in each unit area. Plant density was related to competition between plants in getting sunlight and nutrients. Optimal plant density was closely related to plant growth in need of water, nutrients, and oxygen that was absorbed mainly by the roots and radiation and $\mathrm{CO}_{2}$ absorbed by the leaves under sufficient conditions. Lack of water, nutrients, and light radiation causes plant growth to be hampered so that plant density was not optimal. Based on the survey results and socialization in the group discussion, the targets to be carried out to improve the Arjuna mount forest plants density in the second period of 2019-2020 were (1) preparation of healthy plant seeds; (2) seedlings of various species (endemic plants, springs and fruits); (3) uniform plant height; (4) sufficient nutrient content for plants; (5) availability of water for plants during the dry season; (6) treatment of plants from pest and weed disorders; (7) fertilizer application; (8) sufficient sunlight for plants.

\subsection{Springs preservation}

\subsubsection{Rainy season water discharge}

The constraints faced by spring water discharge in the rainy season were large water discharge and erosion, this was evidenced by the murky water color. The amount of water discharge was due to the overflow of rainwater to absorb vegetation and fill ground water. [14], explained that there were 3 factors that determine the amount of spring discharge was the permeability of the aquifer, the extent of the recharge area that fills the aquifer and the amount of 
groundwater recharge. [47] added that groundwater recharge was determined by rainfall, soil, vegetation and land use, topography and groundwater levels of spring watersheds.

Forest soil erosion occurs due to the overflow of rainfall to the soil and the lack of vegetation condition of the ground cover plants, so that it could not reduce the amount of rainwater damage to the soil. Other contributing factors were not much and not thick litter closing the canopy of plants that cover the soil surface so that it could not reduce the energy of rainwater falling to the ground which could increase the rate of erosion. [46] explained that ground cover plants protect the soil from the destruction of raindrops, slow the surface flow velocity and protect the surface from friction by water.

Some of the successes of improvements that have been made to keep the flow of water sources remain large and avoid erosion in the rainy season was the conservation of springs, one form that has been done was revegetation of the first period of Arjuna mount forest starting in 2014-2018 in water catchment areas, to maintaining hydrological balance in the area of the Lajer, Dawuan, Sumberkuning and Watupereng, Prigen, Pasuruan. The selection of plant species that was in accordance with environmental factors and the area around the spring was needed to support the hydrological aspects of water catchment areas, in order to create a stable ecosystem. The tree species planted around the Lajer spring are banyan (Ficus benyamina), bamboo (Dendrocalamus asper), candlenut (Aleurites moluccana), elo (Ficus racemosa L.) and durian (Durio sp). The tree species planted around the Dawuan spring were petung bamboo (Dendroca-lamus asper), candlenut (Aleurities mollucana), banyan (Ficus benyamina) and bendo (Artocarpus elasticus). The tree species planted around the Sumberkuning springs were petung bamboo (Dendrocalamus asper), mlandingan (Leucaena glauca) and kaliandra (Calliandra calothyrsus). The types of trees planted around the Watupereng spring were petung bamboo (Dendrocalamus asper), banyan (Ficus benyamina), kluweh (Artocarpus communis) and candlenut (Aleurities mollucana).

Based on the results of surveys and socialization in group discussions, the target that will be carried out to maintain the flow of water sources remains large and did not occur erosion in the rainy season of Arjuna mount in second period of 2019-2020 was to carry out a follow-up revegetation program in the area around the spring, by planting springs tree species, namely: petung bamboo (Dendrocalamus sp) 2000 trees, aren (Arenga pinnata) 1000 trees, banyan (Ficus benyamina) 2000 trees and epek (Ficus elastica) 1000 trees in the Curahtangkil village spring area, Dayurejo, Puthukbunder Jatiarjo village and Talangwatu Leduk village.

\subsubsection{Dry season water discharge}

The constraints faced by the discharge of springs in the dry season were dead springs during the dry season of more than 3-4 months. Some of the causes of dead springs include: (1) conversion of forests to agricultural land, resulting in the opening of water catchment areas; (2) illegal logging of protected forests, resulting in decreased soil infiltration, impact on underground water replenishment and increased soil erosion; (3) excessive exploitation of ground water, especially for industrial purposes, results in an imbalance between the addition (recharge) and exploitation (exploitation), so that groundwater reserves are reduced and the discharge of some dead springs. Water catchment areas were areas that have a high infiltration capacity. Groundwater catchment areas relate to places where if there was precipitation fall in the area, water will enter the ground, and provide temporal or permanent addition of ground water reserves. The rate of infiltration or infiltration capacity depends on: rainfall, runoff percentage, soil type, slope, vegetation type, and land use [8].

Some of the successes of improvements that have been made to maintain the flow of spring sources do not die in the dry season were revegetation of the Arjuna mount forest in 2014, in the area around the Lajer spring. Revegetation program by planting 3000 trees, on a 10 hectares water catchment area, several species of trees planted include 1000 bamboo (Dendrocalamus asper), 600 candlenut (Aleurites moluccana), 400 kluwek (Pangium edule), 300 kluweh (Artocarpus communis), 100 banyan (Ficus benyamina), 500 durian (Durio sp) and 100 elo (Ficus glomerata). The measurement results after 3 years of planting are the percentage of living trees $94 \%$, and spring water flow was 10.35 liters/second.

Conducting revegetation of Arjuna mount forest in 2015, in the area around Dawuan spring. Revegetation program by planting 1500 trees, on a 5 hectares water catchment area, several species of trees planted include bamboo petung (Dendroca-lamus asper) 300 trees, candlenut (Aleurities mollucana) 500 trees, banyan (Ficus benyamina) 50 trees, bendo (Artocarpus elasticus) 450 and ivory of 200 trees. The measurement results after 3 years of planting were the percentage of living trees $92 \%$, and the spring water flow was 25.47 liters/second. 
Conducting revegetation of the Arjuna mount forest in 2016, in the area around the Sumberkuning spring. Revegetation program by planting 5000 trees, on a 25 -hectare water catchment area, several species of trees planted include cypress mountain (Casuarina junghuniana) 2000 trees, 300 trees squared, petung bamboo (Dendrocalamus asper) 500 trees, cover (Mallocus moluccana) 200 trees, mlandingan (Leucaena glauca) 500 trees, Calliandra (Calliandra calothyrsus) 1000 trees and gmelina (Gmelina arbora) 500 trees. The measurement results after 3 years of planting were the percentage of living trees $86 \%$, and the spring water flow was 10.25 liters/second.

Carrying out revegetation of Arjuna mount forest in 2017, in the area around the Watupereng spring. Revegetation program by planting 8000 trees, on a 46 hectares water catchment area, some species of trees planted include petung bamboo (Dendrocalamus asper) 1300 trees, banyan (Ficus sp) 500 trees, kluweh (Artocarpus communis) 180 trees, candlenut (Aleurities) mollucana) 450 trees, matoa (Pometia pinnata) 820 trees, cloves (Syzygium aromaticum) 850 trees, soursop (Annona muricata) 800 trees, avocado (Persea americana) 1000 trees, durian (Durio sp) 1200 trees and coffee (Coffea sp) 900 trees. The measurement results after 2 years of planting are the percentage of living trees $99 \%$, and spring water flow was 0.80 liters/second.

The spring protection method that can be applied one of them was by revegetation technique. One of the protection of springs with revegetation techniques was by planting various types of trees. Protection of springs by revegetation can be done in 2 ways, namely (1) planting around the point of spring (radius 10-15) as spring protection; and (2) planting in the recharge area as spring shed protection. The purpose of planting around the spring was more to protect spring points from all pollutants and damage due to human activities. Whereas planting in the groundwater recharge area was expected to help absorb rainwater into the soil which in the long run can fill aquifers, and not become surface runoff. It was expected that the tree planting will protect springs from pollutants, bacteria and harmful chemicals. Thus the sustainability of the spring will be maintained, so that the quality, quantity and continuity of the water flow were met. The results of measurements of water debit from each springs as an indicator that of the springs were still sustainable because the condition of the vegetation of the plant was still able to absorb rainwater presented in Table 5 .

Based on the results of surveys and socialization in group discussions, the target that will be carried out to maintain the flow of springs that did not die in the dry season in the second period of 2019-2020 was to carry out revegetation of the Arjuna mount forest period, in the area around the Sumbertangkil spring in Dayurejo village, Puthukbunder in Jatiarjo village) and Talangwatu in Leduk village. Revegetation program by planting 18000 trees, on an area of 90 hectares of water catchment, several species of trees planted include:

1) Endemic plant species, namely: bendo (Artocarpus elasticus) 1000 trees, kluwek (Pangium edule) 1000 trees, breadfruit (Artocarpus altilis) 1000 trees, candlenut (Aleurites mollucanus) 1000 trees, gondang (Ficus variegate) 1000 trees.

2) Species of spring water plants, namely: petung bamboo (Dendrocalamus sp) 2000 trees, aren (Arenga pinnata) 1000 trees, banyan (Ficus benyamina) 2000 trees, epek (Ficus elastica) 1000 trees

3) Fruit plant species, namely: avocado (Persea americana) 1500 trees, oranges (Citrus sp) 1000 trees, coffee (Coffea sp) 1000 trees, soursop (Annona muricata) 1500 trees, durian (Durio sp) 1000 trees and guava (Psidium guajava) 1000 trees

\subsubsection{Erosion}

Constraints faced with erosion conditions around the water source area were the abundance of large rainwater that was not absorbed by the soil, and the river water flow in the rainy season was turbid. The main factor causing erosion was high rainfall, which was not able to be absorbed in the soil, while other factors observed in the area of the Lajer, Dawuan, Sumberkuning and Watupereng springs include land slope and fragile soil contours. [3], explains that the rate of erosion that occurs was caused by five factors including climate, soil structure and type, vegetation, topography and soil management factors. The climatic factor that most determines the rate of erosion was rain which was expressed in the value of the rain erosivity index. Rainfall that falls directly or indirectly can erode the surface of the soil slowly with increasing time and the accumulation of rainfall intensity will bring erosion.

Some improvement efforts that had been made to prevent erosion around the spring area were the application of soil conservation on land by revegetation of forests in the area around the spring of Lajer, Dawuan, Sumberkuning and Watupereng areas. Soil and land conservation by means of plant vegetation serves to reduce the rate of surface runoff and increase the rate of infiltration of water into the soil. [55], explained that soil conservation by vegetation method was the use of plants or plants and their remnants to reduce the destructive force of falling rain, reduce the amount and destructive force of surface runoff and erosion. The functions of soil conservation were (1) protecting the soil against 
the destructive power of falling raindrops; (2) protect the soil; and (3) increasing the capacity of soil infiltration and water retention which directly affect the amount of surface runoff. Different types of plants or vegetation and land use have different efficiencies in soil conservation. Some forms of conservation actions include: (1) planting of plants that cover the soil continuously; (2) strip cropping; (3) crop rotation with green manure plants or ground cover crops (conservation rotation); (4) forest agriculture system (agroforestry); (5) utilization of plant or plant residues (residue management) and (6) planting drainage channels with grass (vegetated).

Based on the results of surveys and socialization in group discussions, the target to be done to prevent erosion around the spring area was to carry out 90 hectares of land conservation and land around the area of Curahtangkil spring in Dayurejo village, Puthukbunder in Jatiarjo village and Talangwatu in Leduk village. Revegetation program by planting 18000 trees, several species of trees planted include: (1) endemic plant species, namely: bendo (Artocarpus elasticus) 1000 trees, kluwek (Pangium edule) 1000 trees, breadfruit (Artocarpus altilis) 1000 trees, candlenut (Aleurites mollucanus) 1000 trees, gondang (Ficus variegate) 1000 trees; (2) springs plant species, namely: petung bamboo (Dendrocalamus sp) 2000 trees, sugar palm (Arenga pinnata) 1000 trees, banyan (Ficus benyamina) 2000 trees, epek (Ficus elastica) 1000 trees; (3) fruit plant species, namely: avocado (Persea americana) 1500 trees, oranges (Citrus sp) 1000 trees, coffee (Coffea sp) 1000 trees, soursop (Annona muricata) 1500 trees, durian (Durio sp) 1000 trees and guava 1000 trees (Psidium guajava).

\subsubsection{Water economic value}

The constraints faced in maintaining the economic value of the Arjuna mount spring water sources were maintaining the discharge and quality of the water coming out of the dry season springs, which remain large and clear in color. Protection of springs in all forest areas of Arjuna mount did not die in the dry season. Protection of springs was closely related to maintaining the density of land vegetation, strengthening and controlling erosion by planting trees and avoiding the use of insecticides/pesticides in crop management. Planting trees in critical areas, in addition to improving soil structure, also improves the availability of ground water and filters the entry of pollutants into the flow of water that leads to springs. [41] say that improvement of land cover by vegetation was predicted to be able to improve soil permeability.

The economic value of Mount Arjuna springs was a source of water supply that has a large flowrate and quality of water, and the color was clear in the dry season. The economic value of spring water sources was closely related to spring management based on technology and local wisdom [48]. In utilizing springs, technology was needed, which has been carried down through generations by the community, armed with the knowledge and experience they had, so that the springs remain well maintained, because springs were relatively more sustainable in water supply. The integration of spring management combines the characteristics of the spring, the characteristics of the community, the mastery of technology and the culture of the local community. Considering that the use of water from springs was increasingly complex, it was necessary to maintain existing environmental wisdom, especially in the younger generation so that the values of environmental wisdom did not fade. Clear regulations need to be applied to the use of water from springs for purposes outside of household needs, so that the economic value of water did not cause conflicts in the use of springs.

Several improvement efforts have been made to maintain the economic value of the Arjuna mount springs with large water discharge and quality, and its clear color was to increase the vegetation density of the catchment area. Plant vegetation serves to reduce the rate of surface runoff and increase the rate of water infiltration into the soil. Revegetation activities carried out in the area around the springs of Lajer, Dawuan, Sumberkuning and Watupereng, with a total plant area of 19500 trees, and revegetation area of 93 hectares. [14], explained that the 3 factors that determine the amount of spring discharge were the aquifer permeability (ground water level), the extent of the recharge area that fills the aquifer and the amount of ground water recharge. Furthermore [27], states that one of the roles of forest vegetation is to reduce surface runoff. This was because (a) the amount of interception by the canopy of vegetation that was layered and dense, (b) the thickness of litter so that it can accommodate large amounts of water as surface storage and (c) the number of macro pores on the surface of the soil which drives high infiltration rates.

Based on the results of surveys and socialization in group discussions, the target to maintain the economic value of the Arjuna mount springs with large water discharge and quality was to resume forest revegetation in the area around Curahtangkil spring in Dayurejo village, Puthukbunder in Jatiarjo village and Talangwatu in Leduk village. The reforestation of mount Arjuna forest was one of the strategic efforts in increasing the economic value of water, because the tree planting activities in 2019-2020 are coordinated by utilizing all the capabilities of the government, the 
community and environmental observers, as well as companies as providers of funds in rehabilitating forests and land in the water catchment area.

Based on the results of structural equation models analysis in Table 2. and Figure 6., obtained the following results:

(1) $\mathrm{P}$ value of the variable effect of community empowerment on forest revegetation was very significant (***) with

C.R. positive sign of 5.005. Therefore, the p value obtained was > 0.05 and C.R. positive sign and $>1.96$ then H0 was rejected, and concluded that community empowerment has a positive and significant effect on forest revegetation. The better community empowerment, the better the forest revegetation will be, and vice versa [53], explains that there are positive and significant influences of empowerment factors such as profiles, institutions, economics and policies on the productivity of forest rehabilitation. [28], explained that sustainable community development based on the alternative income approach that was environmentally friendly was very important in supporting forest sustainability globally. While [19], states that community empowerment has a positive influence on forest conservation and preventing illegal logging which includes 3 aspects, namely: (1) increased income and the growth of the economy of rural communities with environmental insight; (2) provision of facilities and infrastructure; (3) creation and positive behavior in environmental conservation.

(2) The $p$ value of the influence of geography and land variables on forest revegetation was very significant $(* * *)$ with C.R. positive sign of 6.273. Therefore the $p$ value obtained was $>0.05$ and C.R. positive sign and $>1.96$ then H0 was rejected and concluded that geography and land have a positive and significant effect on forest revegetation. The better the conditions of geographic and soil characteristics, the better the revegetation of the forest, and vice versa. Geographic and land elements that affect forest revegetation are land slope and soil depth. The slope factor or slope affects the erosion that occurs, the greater the percentage of slope on a slope will provide erosivity in increasingly heavy rain, and damage to forest vegetation. While the depth of soil determines the amount of water that can be absorbed by the soil thus affecting the amount of surface flow [5].

(3) P value of the variable effect of community empowerment on the preservation of spring water sources was very significant $(* * *)$ with C.R. positive sign at 4,344 . Therefore the $\mathrm{p}$ value obtained was $>0.05$ and C.R. positive sign and $>1.96$ then $\mathrm{H} 0$ was rejected, and concluded that community empowerment has a positive and significant effect on the preservation of springs. The better the results of community empowerment activities, the better the preservation of springs, and vice versa. [12], explained that the management of water resources based on community empowerment was evidently carried out because of the importance of the environment and the availability of water for the community. Community empowerment strategies for managing water resources include (1) the ability of human resource management to continue to be improved such as professionalism, accountability, management innovation and technology; (2) availability of facilities for springs and (3) encouraging community participation and role for the development of water management technologies [5].

(4) The $p$ value of the influence of geographic and land variables on the profile of forest vegetation was very significant $(* * *)$ with C.R. positive sign of 5.299. Therefore the $\mathrm{p}$ value obtained was $>0.05$ and C.R. positive sign and >1.96, then $\mathrm{H} 0$ was rejected and concluded that geography and land have a positive and significant effect on forest vegetation profile. The better the characteristics of geography and soil conditions, the better the forest vegetation profile, and vice versa. [44], explained that several geographic and soil factors significantly influence the vegetation conditions of protected forests. The factors of slope of land, type of soil and intensity of rainfall are the considerations for the suitability of land to be protected forest areas, forest areas with protected biodiversity. 


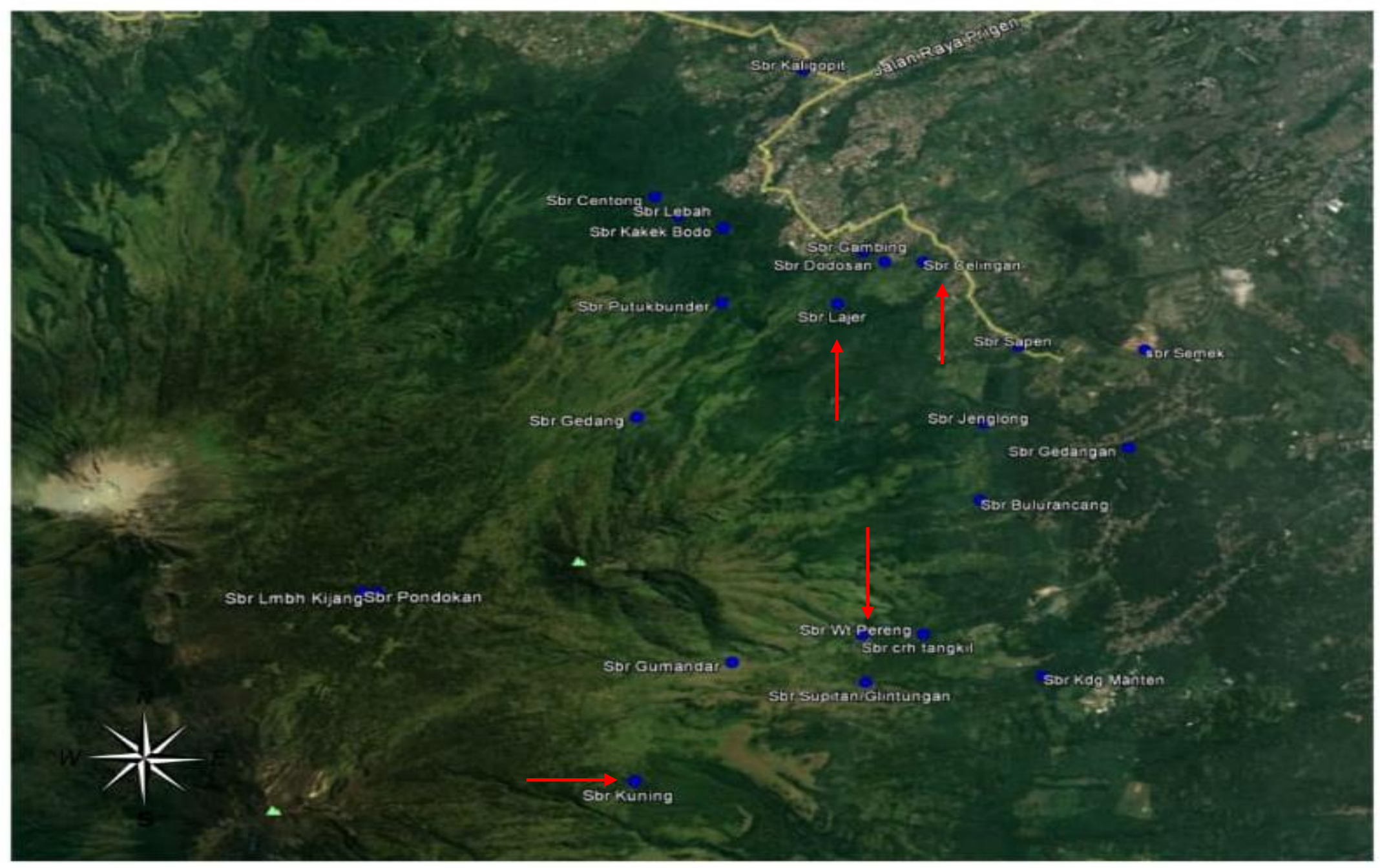

Figure 7. Map of the location of springs in the forest area of Arjuna mount

Note $\longrightarrow$ : Springs location in Lajer, Dawuan, Celingan, Sumberkuning and Watupereng 
Table 5. Condition of springs in conservation and forestry areas of Arjuna mount, Pasuruan East Java

\begin{tabular}{|c|c|c|c|c|c|c|}
\hline NO & Springs name & Location & Village & $\begin{array}{c}\text { Elevation } \\
\text { (meters above sea level) }\end{array}$ & Coordinate & $\begin{array}{l}\text { Water discharge } \\
\text { (liter/second) }\end{array}$ \\
\hline 1 & Lembah Kijang & Pecalukan & Pecalukan & 2484 & $07^{\circ} 44^{\prime} 36,8^{\prime \prime}$ LS $112^{\circ} 35^{\prime} 46^{\prime \prime} \mathrm{BT}$ & 2,08 \\
\hline 2 & Gumandar & Gumandar & Dayurejo & 2100 & $07^{\circ} 42^{\prime} 30,3^{\prime \prime}$ LS $112^{\circ} 36^{\prime} 35,8^{\prime \prime} \mathrm{BT}$ & 21,05 \\
\hline 3 & Sumber Kuning & Sumber kuning & Jatiarjo & 1960 & $07^{\circ} 45^{\prime} 54^{\prime \prime} \mathrm{LS} 112^{\circ} 37^{\prime} 07,6^{\prime \prime} \mathrm{BT}$ & 10,25 \\
\hline 4 & Putu Bunder & Putuk bunder & Dayurejo & 1119 & $07^{\circ} 42^{\prime} 36,7^{\prime \prime} \mathrm{LS} 112^{\circ} 37^{\prime} 30,6^{\prime \prime} \mathrm{BT}$ & 14,16 \\
\hline 5 & Sumber Gedang & Pecalukan & Pecalukan & 1900 & $112^{\circ} 37^{\prime} 04,1^{\prime \prime}$ BT $07^{\circ} 43^{\prime} 26,1^{\prime \prime}$ LS & 4,70 \\
\hline 6 & Pondokan & Pecalukan & Pecalukan & 1700 & $112^{\circ} 35^{\prime \prime} 41,8^{\prime}$ ВТ $07^{\circ} 44^{\prime} 36,8^{\prime \prime} \mathrm{LS}$ & 2,08 \\
\hline 7 & Bulurancang & plot $42 \mathrm{C}$ & Dayurejo & 832 & $07^{\circ} 44^{\prime} 00,1^{\prime \prime} \mathrm{LS} 112^{\circ} 39^{\prime} 03,1^{\prime \prime} \mathrm{BT}$ & 1,37 \\
\hline 8 & Jenglong & plot 43 & Dayurejo & 792 & $07^{\circ} 43^{\prime} 26.56^{\prime L S} 112^{\circ} 39^{\prime} 4.19^{\prime \prime} \mathrm{BT}$ & 3,27 \\
\hline 9 & Supitan & plot 31 & Jatiarjo & 1172 & $07^{\circ} 45^{\prime} 17,7^{\prime \prime} \mathrm{LS} 112^{\circ} 38^{\prime} 23,8^{\prime \prime} \mathrm{BT}$ & 1,50 \\
\hline 10 & Kedungmanten & plot 35 & Jatiarjo & 837 & $07^{\circ} 45^{\prime} 16,0^{\prime \prime} \mathrm{LS} 112^{\circ} 39^{\prime} 26,9^{\prime \prime} \mathrm{BT}$ & no water \\
\hline 11 & Curah Tangkil & plot 36 & Dayurejo & 1026 & $07^{\circ} 44^{\prime} 57,6^{\prime \prime} \mathrm{LS} 112^{\circ} 38^{\prime} 43,7^{\prime \prime} \mathrm{BT}$ & dry \\
\hline 12 & Watu Pereng & plot 35 & Dayurejo & 1159 & $07^{\circ} 44^{\prime} 57,6^{\prime \prime} \mathrm{LS} 112^{\circ} 38^{\prime} 22,1^{\prime \prime} \mathrm{BT}$ & 0,80 \\
\hline 13 & Gumer/Semek & Taman Dayu area & Dayurejo & 550 & $07^{\circ} 42^{\prime} 52.95^{\prime \prime} \mathrm{LS} 112^{\circ} 40^{\prime} 2.70^{\prime \prime} \mathrm{BT}$ & 0,19 \\
\hline 14 & Sapen & plot $43 \mathrm{a}$ & Ledug & 648 & $7^{\circ} 42^{\prime} 52.68^{\prime \prime}$ LS $112^{\circ} 39^{\prime} 16.17^{\prime \prime}$ BT & 0,49 \\
\hline 15 & Lajer & plot $51 \mathrm{~g}$ & Ledug & 925 & $07^{\circ} 42^{\prime} 35,7^{\prime \prime} \mathrm{LS} 112^{\circ} 38^{\prime} 11,0^{\prime \prime} \mathrm{BT}$ & 10,35 \\
\hline 16 & $\begin{array}{l}\text { Sumber } \\
\text { Gambing }\end{array}$ & Plot 50a & Ledug & 652 & $07^{\circ} 42^{\prime} 12,7^{\prime \prime}$ LS $112^{\circ} 38^{\prime} 19,7^{\prime \prime} \mathrm{BT}$ & 28,86 \\
\hline 17 & Centong & plot $54 \mathrm{~b}$ & Pecalukan & 948 & $07^{\circ} 41^{\prime} 50.83^{\prime \prime L S} 112^{\circ} 37^{\prime} 5.57^{\prime \prime} \mathrm{BT}$ & no water \\
\hline 18 & Kakek Bodo & plot $53 \mathrm{e}$ & Tretes & 1100 & 742'3.64" LS112 37'29.83" BT & 1,89 \\
\hline 19 & Sumber Lebah & plot $53 \mathrm{a}$ & Pecalukan & 946 & $07^{\circ} 41^{\prime} 59,0^{\prime \prime} \mathrm{LS} 112^{\circ} 37^{\prime} 14,0^{\prime \prime} \mathrm{BT}$ & 0,54 \\
\hline 20 & $\begin{array}{l}\text { Sumber Kali } \\
\text { Gopit }\end{array}$ & plot $3 \mathrm{f}$ & Lumbang & 572 & $07^{\circ} 40^{\prime} 51,7^{\prime \prime} \mathrm{LS} 112^{\circ} 37^{\prime} 56,7^{\prime \prime} \mathrm{BT}$ & 36,58 \\
\hline 21 & Celingan & plot $43 d$ & Ledug & 596 & $07^{\circ} 42^{\prime} 16,1^{\prime \prime} \mathrm{LS} 112^{\circ} 38^{\prime} 41,3^{\prime \prime} \mathrm{BT}$ & 4,03 \\
\hline 22 & Dodosan & plot 42 & Ledug & 639 & $07^{\circ} 42^{\prime} 16,7^{\prime \prime} \mathrm{LS} 112^{\circ} 38^{\prime} 27,5^{\prime \prime} \mathrm{BT}$ & 3,67 \\
\hline 23 & Dawuhan & plot 51 & Ledug & 652 & $07^{\circ} 42^{\prime} 11,3^{\prime \prime} \mathrm{LS} 112^{\circ} 38^{\prime} 20,3^{\prime \prime} \mathrm{BT}$ & 25,47 \\
\hline 24 & $\begin{array}{l}\text { Sumber } \\
\text { Gedangan }\end{array}$ & Tegal Gamoh & Dayurejo & 600 & 743'36.47" LS $112^{\circ} 39^{\prime} 57.15^{\prime \prime} \mathrm{BT}$ & dry \\
\hline
\end{tabular}

Source: [39] 
(5) The value of the $p$ value of the effect of forest revegetation variables on the preservation of springs was very significant $(* * *)$ with C.R. positive sign at 5.760. Therefore the p value obtained was $>0.05$ and C.R. positive sign and $>1.96$, then $\mathrm{H} 0$ was rejected and concluded that forest revegetation has a positive and significant effect on the preservation of springs. The better the forest revegetation, the better the preservation of springs, and vice versa. Vegetation closure plays an important role in regulating the hydrological system, especially the "sponge effect" which can hold rainwater and regulate the flow so as to reduce the tendency of flooding and maintain the flow of water in the dry season. This function will be lost if the vegetation in the higher watershed was lost or damaged. Throughout the tropics, $90 \%$ of farmers in the lowlands depend on the activities of $10 \%$ of the people living in the upper reaches of the river [34]. In an effort to conserve springs, one method that can be used was by vegetation methods, through programmed rehabilitation in water catchment areas, to support hydrological balance in the area of the springs [14]. [40], explained that one of the efforts to protect and preserve the recharge area was among others: conducting agronomic conservation activities, carrying out mechanical conservation activities and regulation of the border of the water source.

(6) The $p$ value of the effect of the forest revegetation variable on the profile of forest vegetation was very significant (0.002) with C.R having a positive sign of 3.084. Therefore the value of $\mathrm{p}$ value obtained > 0.05 and C.R was positive and $>1.96$, then $\mathrm{H} 0$ was rejected and concluded that forest revegetation has a positive and significant effect on forest vegetation profile. The better the forest revegetation, the better the forest vegetation profile, and vice versa. [42], describe healthy forest or forest sustainability indicators from revegetation that have been carried out, among others: vegetation cover that was quite tight, the hydrologic cycle was well maintained, soil fertility was maintained, the interaction between biotic and abiotic factors does not cause damage and succession takes place well. Biodiversity was also used for assessing indicators of forest sustainability or forest health.

(7) The value of $p$ value of the effect of forest vegetation profile variable on the preservation of spring water source was very significant $(0.004)$ with C.R having a positive sign of 2.914 . Therefore the value of $\mathrm{p}$ value obtained $>0.05$ and C.R was positive and $>1.96$, then H0 was rejected and concluded that the profile of forest vegetation has a positive and significant effect on the preservation of springs. The better the profile of forest vegetation, the better the preservation of springs, and vice versa. Components of vegetation profile such as canopy, litter/humus and root system, play an important role in maintaining the water system, namely in terms of: evaporating water (transpiration), applying water to the soil, reduce the kinetic power of rainwater grains, enlarge the capacity of land, to store water in the soil, reduce runoff and reduce soil erosion [45].

\section{Conclusion}

Conclusions of the results of the research include: (1) community empowerment factors, namely human resources, economic, social, local institutions, facilities and infrastructure, have a very significant effect on forest revegetation; (2) geographic and land variables have a significant effect on forest revegetation; (3) forest revegetation variables have a significant effect on the preservation of spring sources; (4) the development of human resources, economic, local institutional, facilities and infrastructure in the community around the forest was a relevant model for the success of forest revegetation and the preservation of springs in Arjuna mount.

Community empowerment in the form of human, economic, social, local institutions, facilities and infrastructure has a positive influence on forest conservation and can prevent illegal logging, natural forest fires during the dry season, making forest charcoal by the community and opening up agriculture in forest areas.

- Analysis of human resource capital for community empowerment in the preservation of the Arjuna mount forest, with the perception value of respondents agreeing to be $57.6 \%$

- Analysis of economic capital for community empowerment in the preservation of the Arjuna mount forest, with the perception value of the respondents agreeing to be $55.3 \%$

- Analysis of social capital for community empowerment in the preservation of the Arjuna mount forest, with the perception value of respondents agreeing to be $52.3 \%$

- Analysis of institutional capital for community empowerment in the preservation of the Arjuna mount forest, with the perception value of respondents agreeing to be $54.3 \%$

- Analysis of the capital of facilities and infrastructure for community empowerment in the preservation of the Arjuna mount forest, with the value of perceptions of respondents agreeing to be $55.2 \%$

Geographic and land in the form of land slope and effective soil depth has a significant effect on forest revegetation, because almost $57.6 \%$ of respondents expressed strongly agree and agree with the profile of the slope of the land for revegetation of Arjuna mount forest, while the effective soil depth conditions 
around the springs affect the success of revegetation of the Arjuna mount forest, because almost 53.3\% of respondents expressed strongly agree and agree.

Arjuna mount forest revegetation to the springs preservation in around area of Lajer, Dawuan, Sumberkuning and Watupereng springs, Pasuruan of East Java, Indonesia with the following results:

- The revegetation plant species of Arjuna mount forest influence the preservation of the Lajer, Dawuan, Sumberkuning and Watupereng springs, because almost $59.1 \%$ of respondents stated strongly agree and agree

- The nursery of Arjuna mount forest revegetation affects the preservation of the Lajer spring, Dawuan, Sumberkuning and Watupereng springs, because almost $56.2 \%$ of respondents stated strongly agree and agree

- The fertilization of Arjuna mount forest vegetation affects the preservation of the Lajer spring, Dawuan, Sumberkuning and Watupereng springs, because almost $58.1 \%$ of respondents agreed and strongly agreed

- The planting of Arjuna mount forest trees influence the preservation of the Lajer, Dawuan, Sumberkuning and Watupereng springs, because almost $57.6 \%$ of respondents agreed and strongly agreed

- The plant care of Arjuna mount forest vegetation influence the preservation of the Lajer, Dawuan, Sumberkuning and Watupereng springs, because almost $56.5 \%$ of respondents said they agree and strongly agree

Estimated regression weights for each indicator of community empowerment in Leduk, Jatiarjo and Dayurejo villages include the following: human resources 0.99 , economy 0.99 , social 0.97 , local institutions 1.00 and facilities and infrastructure 1.00. This condition shows that according to respondents the local institutional factors, facilities and infrastructure have a significant influence on community empowerment for the preservation of the Arjuna mount forest.

\section{References}

[1] Adekola, Ganiyu, Mbalisi and O. Festus. 2015. Conserving and preserving forest and forest resources in

[2] Anggita T., 2013. Social capital support in collective farming business to support agricultural production performance case study: Karawang and Subang regencies. Journal of Regional and City Planning. 24 (3): Page. 203-226

[3] Arsyad S., 2000. Soil and water conservation. New edition. IPB publisher (IPB press), Bogor

[4] Ashraf, S. and B. Normohammadan. 2011. Qualitative Evaluation of Land Suitability for Wheat in NortheastIran Using FAO Methods. Indian Journal of Science and Technology, 4(6):703-707

[5] Anwar, Makmur H. and R. Pranata, 2014. Community-based water governance empowerment strategy in Banyuwangi district. Faculty of social and political sciences, University of Jember

[6] Arsyad, S. 2000. Soil and water conservation. New edition. IPB Press (IPB Press), Bogor

[7] Awang S.A.,, W.T. Widayanti, B. Himmah, A. Astuti, R.M. Septiana, Solehudin and Novenanto A., 2008. Guide to empowering forest village community institutions. French agricultural research center for international development research unit forest resources and public policies

[8] Balek, J., and Simmers, I. 1988. Estimation of Natural Groundwater Recharge. Dordrecht: D. Reidel Publishing Company.

[9] Basyuni, M. 2002. Guide to restoration of damage mangrove forests. University of North Sumatra digital library

[10] Budihardjo E., 1993. Environmentally friendly city. Bandung. Alumni

[11] Budiawan, Arifin H. and K. Suprayogi. 2012. Training manual: Nursery techniques and silviculture, plant planting and maintenance, financial management and management. Technical report - volume 3. Ministry of forestry Republic of Indonesia. directorate general of forestry business development and international tropical timber organization (ITTO). Jakarta.

[12] Buwono N.R., G.O. Muda and S. Arsad, 2017. The management of Sumberawan wellspring based on the community in the Toyomarto village Singosari district Malang regency. Scientific journal of fisheries and maritime affairs (ISSN: 2085-5842). Water resources management study program. Faculty of fisheries and marine sciences, Brawijaya university Malang

[13] Danu. 2004. Potensi Produksi Benih di Jawa. Potential seed production in Java. Proceedings of the integrated expose of research results. Forestry research and development agency. Ministry of forestry. Pages 10-25

[14] Davis S.N and De Wiest RJM. 1966. Hydrogeology. John Willey and Sons. New York 
[15] Darmanto and Weningsih S, 2014. Strengthening institutions of forest village community institutions. Scientific research report. Open university

[16] Dewanto, F.G., J.J.M.F. Londok, R.A.F. Tuturoong, and W.B. Kaunang, 2013. Effect of inorganic and organic feed on corn production as feed sources. Zootek Journal. 32 (5): 1-8. ISSN. 0852-2626

[17] Dewi A, P.K. 2011. Effects of education level, influence, attitudes and exposure to public service announcements. Jakarta. Bandung University. Journal of education level. 10:11 2011

[18] Dolezal, J. and M. Srutek. 2002. Altitudinal changes in composition and structure of mountaintemperate vegetation: A case study from western carpathians. Journal of plant ecology 158 (16):201-221

[19] Effendi, R., I. Bangsawan and M.M. Zahrul, 2014. Study of patterns of community empowerment around production forests in preventing illegal logging. Journal of forestry social and economic research. Vol. 4 No. December 4, 2007, p. 321 - 340

[20] Ferdinand, A. 2006. Structural equation modeling (SEM) in management research. Master of management program at Diponegoro University. Diponegoro University publishing agency

[21] Fukuyama F., 2007. Trust: social virtue and creation of prosperity. Yogyakarta [ID]: Qalam Publisher. Page. 563

[22] Garjita, P., Susilowati I. dan T. Retnoningsih, 2014. Community empowerment strategy for the Ngudi Makmur forest farmers group in the vicinity of mount Merapi national park. Journal of ecosciences. Vol. VI. No. 1. Postgraduate environmental sciences Diponegoro University Semarang

[23] Gaston, K.J. and J.I. Spicer, 1998. Biodiversity: an introduction. Blackwell science. Oxford; Malden. Ma. USA

[24] Ghozali I., 2014, Structural equation modeling, alternative method with partial least square (PLS), 4th Edition, Semarang: Diponegoro university publishing agency

[25] Ginting A.N., Siregar C.A., Masano, Hendromono, Mile M.Y. and Hidayat. 1995. Guidelines for selecting forest tree plant types and land suitability. Jakarta

[26] Graha, A.N., 2009. Community development through social assistance in the concept of empowerment in the economy. Journal of modernization economics. Faculty of economics, Kanjuruhan University of Malang. Page. 117-127

[27] Hairiah K., D. Suprayogo, M. Apriyanti, Y. W. Wahyudi and N. Qhomariyah, 2015. Greening in the Kalikonto watershed: Soil fertility in the agroforestry system after the Kelud mount eruption. National proceedings of the agroforestry seminar. Faculty of agriculture. Brawijaya University

[28] Haque, M.Z., Reza, M.I.H., Alam, M., Z.U. Ahmed and W. Islam, 2016. Discovery a potential site for community-based sustainable eco tourism in the sundarbans reserve forest, Bangladesh. International journal of conservation science. ISSN: 2067-533X. Vol. 7. Issue 2, April-June 2016: 553-566

[29] Hardjowigeno, S. 2007. Soil science. Third edition. PT. Mediyatama means mighty. Jakarta

[30] Indrawan M, Primack RB, SupriatnaJ. 2007. Biology conservation. Obor foundantion Indonesia, Jakarta

[31] Indriyanto, 2006. Forest ecology. Jakarta: Bumi aksara publisher

[32] Leksono, A.S., 2011. Biodiversity: theory and application. Universitas Brawijaya Press. UB Press

[33] Li, W., Y. Zhang, C. Wang, W. Mao, T. Hang, M. Chen, and B. Zhang. 2013. How to Evaluate the Rice Cultivation Suitability?. Asian Agricultural Research, 5(12):59-64.

[34] MacKinnon, J., MacKinnon, K., Child, G., Thorsell, J. 1990. Management of protected areas in tropical areas. Gadjah Mada University press. Yogyakarta

[35] Mardiastuti A, Salim LR, Mulyani YA. 2001. Sulawesi hornbill eating behavior on two types of Ficus in Lambusango wildlife reserve, Buton. Conservation media. 6 (1): 7-10.

[36] Nath, T.N. 2013. The macronutrients status of long term tea cultivated soils in Dibugrah and Sivasgar districts of Assam, India international journal of scientific research. 2(5):273-275

[37] Nurhasybi and Dede J. Sudradjat. 2002. Relationship between tree age and production potential and seed quality of several forest plant types. Seed techno. Vol. 7 No. 2. 2002. Research and development center for biotechnology and forest plant breeding. seed technology research and development center. Bogor

[38] Onrizal, 2005. Enrichment planting for rehabilitation of former felling forests using line planting techniques. E-USU repository. University of Northern Sumatra

[39] PT. Sorini Agro Asia Corporindo, 2017. Forest rehabilitation program for Arjuna mount forest. Prigen Pasuruan

[40] Riastika, 2012. Conservation-based groundwater management in Boyolali area recharge (case study of Cepogo area recharge, Boyolali, central Java): Journal of environmental sciences. Vol. 9, issue 2: 86-97 (2012), Environmental studies program of UNDIP Postgraduate

[41] Rohmat D. and Soekarno I., 2006. Formulation of effects of soil physical properties on soil permeability and suction head (Empirical studies to increase infiltration rates). Journal of Bionatura 8 (1) 
[42] Safei, R.S. and M.K. Tsani, 2016. Forest health. Forest health assessment using forest health monitoring techniques. Plantaxia. Yogyakarta

[43] Santoso I., 2015. Changes in culture of forest edge farmers in the development of social capital based forest resource management. Journal of rural development: Vol. 7 No. 1: Diponegoro University.

[44] Schwab, G.O., Fangmeir, D.D., Elliot, W.J., and Frevert, R.K. 1992. Soil ang Water Conservation Engineering. Four Edition, John Wiley \& Sons. Inc, New York.

[45] Soerianegara I. and Indrawan. 1978. Indonesian forest ecology. Faculty of IPB. Bogor

[46] Sofiah, S., and Fiqa, AP. 2014. Types of trees around the springs of the highlands and lowlands (case study of Malang regency). Kebun Raya Purwodadi-LIPI, Pasuruan

[47] Sophocleous M.A., McAllister J.A., 1987. Basinwide water-balance modeling with emphasis on spatial distribution of ground-water recharge. Water Resour Bull 23(6):997-1010

[48] Sudarmadji, Darmanto, D., Widyastuti, M., and Lestari S., 2014. Integration of technology and local wisdom in the management of springs for provision of sustainable household water. Research report. UGM postgraduate school. Yogyakarta

[49] Sumodiningrat G., 1999. Community empowerment and social safety net. Jakarta. Gramedia. Utama Library

[50] Supranto, J. 2004. Research proposal by research. UI Press. Jakarta

[51] Suryana, 2006. Development Economics: Problems and Approaches. Jakarta. Salemba four

[52] Tjakrawarsa G. and C. Handoko, 2013. Study of springs protection techniques on Lombok Island: a case study in KHDTK Rarung (study of technique protection of springs at Lombok Island case study at the Rarung research forest). Indonesian center for forestry technology research institute for forest rehabilitation Journal Vol. 1 No. 1, September 2013: 1-15

[53] Wakarmamu T., Bura S.T. and A. Lamba, 2015. Analysis of factors affecting the productivity of forest rehabilitation, land and its benefits to communities in Yahukimo regency. Journal of bureaucratic ecology. Vol. 1, No. 1. page. 1-21

[54] Widjajanti, K. 2011. Community empowerment model. Journal of development economics. Volume 12, number 1 June 2011. Faculty of economics, Semarang University. Page. 15-27

[55] Wischmeier W.H., and D.D. Smith. 1978. Predicting Rainfall Erosion Lossess: A guide to Conservation Planning USDA Handbook No 537. Washington DC.

[56] Wiyono, A. 2008. Preservation of the forest park raya R. Soerjo to maintain water supply and biodiversity. Kaliandra sejati foundation, Gamoh Village, Dayurejo Village, Prigen, Pasuruan. USAID 